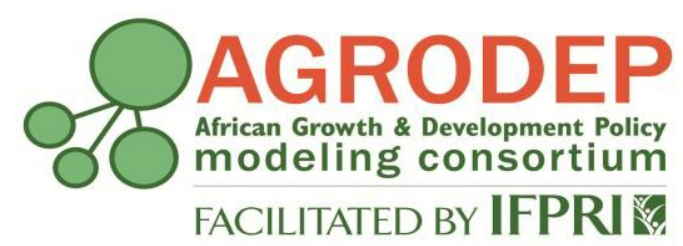

AGRODEP Working Paper 0043

April 2020

\title{
African Commitments for Agricultural Development Goals and Milestones for Ethiopia
}

\author{
Lulit Mitik \\ Ismael Fofana \\ Mariam Diallo
}

AGRODEP Working Papers contain preliminary material and research results. They have been peer reviewed but have not been subject to a formal external peer review via IFPRI's Publications Review Committee. They are circulated in order to stimulate discussion and critical comments; any opinions expressed are those of the author(s) and do not necessarily reflect the opinions of AGRODEP. 


\begin{abstract}
About the Authors
Lulit Mitik is a researcher at Modelling and Policy Impact Analysis (MPIA) of the Partnership for Economic Policy (PEP).

Ismael Fofana is a Research Fellow at the Africa Division of the International Food Policy Research Institute (IFPRI).

Mariam Diallo is a Research Analyst at the Africa Division of the International Food Policy Research Institute (IFPRI).
\end{abstract}

\title{
Acknowledgements
}

This study was carried out for the Program of Accompanying Research for Agricultural Innovation (PARI) as part of the cooperation between the Center for Development Research (ZEF) and the International Food Policy Research Institute (IFPRI). We benefitted from helpful and valuable comments from anonymous reviewers at ZEF. We are grateful to Fleur Wouterse for the support and the coordination of the research and the German Federal Ministry for Economic Cooperation and Development (BMZ) for funding this work through PARI, as part of the One World, No Hunger Initiative (SEWOH) by the German Government. This work was carried out with technical support and guidance form Ismael Fofana. Mariam Diallo and Anatole Goundan have been instrumental in the exploitation of the CGE and micromodels in particular by running the numerous simulation scenarios and preparing the results tables and figures. The authors are very grateful to all. 
Table of Contents

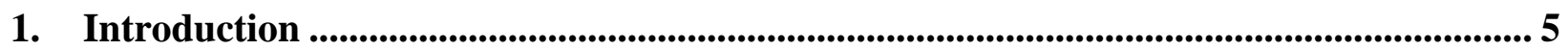

2. Policy Coherence and Agricultural Development Goals.................................................... 7

3. Methods and data ................................................................................................................. 14

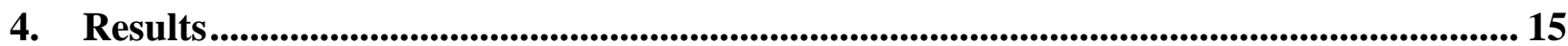

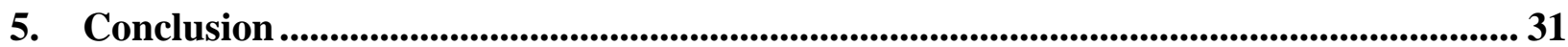

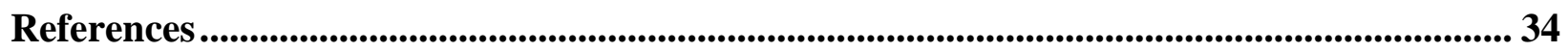

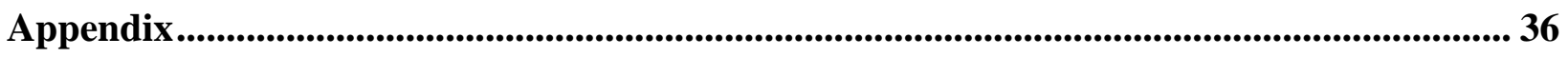

AGRODEP Working Paper Series.......................................................................................... 37 


\begin{abstract}
The study developed a results framework to analyze Ethiopia's progress towards selected CAADP/Malabo, SDGs and Agenda 2063 goals. A Computable General Equilibrium model linked to an income distribution Micro-Simulation model were used to identify priority investment areas for accelerated agricultural growth, poverty and inequality reduction. Simulation results indicate that the current investment trend and composition would leave Ethiopia off-track to meet these objectives. The analysis of alternative agricultural investment scenarios shows that the public sector has still a great role to play in promoting agricultural growth in Ethiopia. Past expenditure levels have been high, though not sufficient, and would need to increase substantially with an emphasis on the quality of public agricultural spending. Productivity remains one of the major challenges but also one of the most effective solutions for accelerated agricultural growth in Ethiopia. Agricultural investments should be designed considering the agricultural value-chain. While social protection programs are important for the poor, rural non-agricultural development could provide a more sustainable source of income.
\end{abstract}

\title{
Resume
}

L'étude a élaboré un cadre de résultats pour analyser les progrès de l'Éthiopie vers certains objectifs du PDDAA / Malabo, des ODD et de l'Agenda 2063. Un modèle d'équilibre général calculable lié à un modèle de micro-simulation de répartition des revenus a été utilisé pour identifier les domaines d'investissement prioritaires pour l'accélération de la croissance agricole, la pauvreté et la réduction des inégalités. Les résultats de la simulation indiquent que la tendance et la composition actuelles des investissements laisseraient l'Éthiopie sur la mauvaise voie pour atteindre ces objectifs. L'analyse des scénarios alternatifs d'investissement agricole montre que le secteur public a encore un grand rôle à jouer dans la promotion de la croissance agricole en Éthiopie. Les niveaux de dépenses antérieurs ont été élevés, mais pas suffisants, et devraient augmenter considérablement en mettant l'accent sur la qualité des dépenses publiques agricoles. La productivité reste l'un des défis majeurs mais aussi l'une des solutions les plus efficaces pour accélérer la croissance agricole en Éthiopie. Les investissements agricoles devraient être conçus en tenant compte de la chaîne de valeur agricole. Bien que les programmes de protection sociale soient importants pour les pauvres, le développement rural non agricole pourrait fournir une source de revenus plus durable. 


\section{Introduction}

Building on the Comprehensive Africa Agriculture Development Programme (CAADP) signed by African Heads of State (AU/NEPAD, 2003), the 2014 Malabo Declaration on Accelerated Growth and Transformation for Shared Prosperity and Improved Livelihoods upheld the original Maputo commitment of achieving a $6 \%$ annual agricultural growth rate and a $10 \%$ agricultural expenditure as share of total public expenditure (AU/NEPAD, 2014). The seven priority areas of the 2014 Malabo Declaration marked a strong commitment to the goals of improving investments in agricultural production, ending hunger and halving poverty, boosting intra-African trade in agricultural commodities and services, enhancing resilience to climate variability and other related risks, as well as the goal of creating mutual accountability to actions and results through a review process of the progress made in implementing the provisions of the Declaration. At the same time, countries have signed on to the African Union (AU) Agenda 2063 as well as the United Nations (UN) Sustainable Development Goals (SDGs) - which are committed to accelerating economic growth and eradicating poverty and inequality, among several other goals. A key challenge to implementing these commitments is that they involve many obligations and goals.

To address the CAADP/Malabo, SDGs and Agenda 2063 goals, a Results Framework for 2015-2025, 20162030 and 2014-2035, respectively, has been developed as a key tool for translating Africa's agricultural agenda into tangible outcomes. This paper applies this Results Framework for Ethiopia. The application of the result frameworks also considers Ethiopia's national policies that have been developed and aligned to these continental and global policy frameworks. The policies considered include those outlined in the Growth and Transformation Plan II (GTP II). The Results Framework assists the tracking, monitoring and reporting on progress as well as facilitating mutual learning and accountability for Ethiopia. The goals are organized into two broader areas with two sets of metrics that have been identified to measure targets, define milestones, and guide progress and performance tracking and review. The first area deals with overarching goals and targets as derived from the 2003 CAADP and recommitted under the 2014 Malabo Declaration, which include achieving $6 \%$ annual agricultural growth, reaching a $10 \%$ agricultural expenditure share, eliminating hunger, and halving poverty by 2025. These overarching goals are aligned with SDGs 1 (end poverty) and 2 (end hunger and promote sustainable agriculture) as well as Agenda 2063 goal 5 (modernise agriculture for increased production) and goal 1 (quality of life and wellbeing for all citizens). Moreover, these overarching goals are aligned to the objectives of the GTP 2.

The second area covers metrics detailing sub-goals and targets that are made under each of the specific thematic areas covered under Ethiopia's national policies, CAADP/Malabo Declaration, Africa's Agenda 2063 and SDGs. It must be noted that Agenda 2063 and SDGs also contain goals for non-agricultural sectors, some of which are considered for this analysis. The goals analysed in the second area under 
CAADP/Malabo include: agricultural investments; ending hunger; ending poverty and intra-Africa trade. Under the SDGs the goals analysed include halving poverty; ending hunger; sustainable economic growth; inclusive and sustainable industrialization and reducing poverty. Finally, under Agenda 2063, the goals analysed include poverty reduction, hunger eradication, inequality reduction, increase in employment and incomes, inclusive economic growth, productivity growth and intra-Africa trade. Under each of these, relevant indicators in the Results Framework are considered and additional complementary metrics are proposed and used to ensure that status assessment and program and investment plan designs are comprehensive enough to meet the vision outlined by the three Agendas including the country policies.

The analytical approach proposed here addresses the overarching goals and targets. It uses economic modeling to assess Ethiopia's current economic and agricultural growth path against predefined agricultural development goals and targets. The modeling tool is also used to identify priority areas for investment in agriculture and to define the milestones to achieving the predefined agricultural development goals. The economic modeling tools consist of a Computable General Equilibrium (CGE) model linked to an income distribution Micro-Simulation (MS) model to assess the poverty outcomes of public agricultural investments. Finally, The CGE model is used to identify priority agricultural commodities based on their contributions on agriculture GDP growth and consumption growth rate. The models are used to construct a Business as Usual scenario which demonstrates the expected impacts of a continuation of recent economic trends on development goals, as well as an agricultural investment scenario of accelerated agricultural growth.

Agriculture has been the main driver of economic growth and poverty reduction in Ethiopia up to 2015. Real agricultural GDP grew at an average of 6.6 per annum between 2010-11 and 2014-15. Although gradually declining, the share of agriculture and related activities in overall GDP represented 50 percent on average until 2002-03 reaching 41.5 percent between 2010-11 and 2014-15. Agriculture provides the main source of livelihood to the country's rural population. It is the largest employer concentrating 74 percent of the labor force. The sector also provides the bulk of export commodities (over 75 percent of total) with export revenue from agricultural production representing 3.6 percent of GDP between 2010-11 and 201415. Agriculture has been at the center of the successive development programs in Ethiopia. The current medium-term development plan, the Growth and Transformation Plan II (GTP II) aims at maintaining the growth performance attained during the past years (10 percent on average) with agriculture as the primary driver of growth. Crop production is particularly important in Ethiopia. Over 70 percent of agricultural GDP derives from crop production, in particular grain crops. Cereals dominate the crop sector accounting for 80.7 percent of total cultivated area in 2014-15 and engaging 13.3 million small holders. Maize is Ethiopia's largest cereal commodity in terms of total production, yield and the number of farm holdings. Ethiopian agriculture is dominated by smallholder farmers. Ethiopia’s expenditures on agriculture as a share 
of total public expenditure averaged 8.9 percent per year during 1995-2003, 15.4 percent per year during 2003-2008, and 11.9 percent per year during 2008-2014 (ReSAKSS). Between 2010 and 2015, the share of agriculture in total public expenditure averaged 9.3 percent per year. Regarding poverty reduction, Ethiopia has done well on the Millennium Development Goals (MDGs): share of population living below poverty line fell from $44 \%$ in 2000 , to $30 \%$ in 2010 , and to $23.4 \%$ by $2015^{1}$.

\section{Policy Coherence and Agricultural Development Goals}

The second Growth and Transformation Plan (GTP II) builds upon the national macroeconomic and sectoral development policies, strategies and programs, and the lessons drawn from the implementation of the first Growth and Transformation Plan (GTP I). The plan seeks to integrate and mainstream the principles of the Agenda 2030 for Sustainable Development and the Agenda 2063, among others, in view of domesticating the policies, strategies and development priorities (Table 1). The GTP II has the overarching objective of sustaining an accelerated growth and thrives to achieve the country's vision of transforming into a lower middle-income economy by 2025. It is designed for the period 2015/16-2019/20.

The four specific objectives are presented below as outlined in the plan. First, achieve an annual average real GDP growth rate of 11 percent within a stable macroeconomic environment and thereby contribute towards the realization of Ethiopia's vision of becoming a lower middle-income country by 2025, while pursuing comprehensive measures towards narrowing the saving-investment gap and bridging the widening trade deficit. Second, develop the domestic engineering and fabrication capacity and improve productivity, quality, and competitiveness of the domestic productive sectors (agriculture and manufacturing industries) to speed up structural transformation. Third, further solidify the on-going public mobilization and organized participation to ensure the public become both owners and beneficiaries from development outcomes. Finally, deepen the hegemony of developmental political economy by strengthening a stable democratic developmental state.

In the GTP II, agriculture remains the one of main drivers of growth. In parallel, the plan has the ambition to make Ethiopia a leading country in light manufacturing in Africa.

\footnotetext{
${ }^{1}$ Source: National Planning Commission, HICE report 2015
} 
Table 1: Indicators of strategic agricultural impact areas

\begin{tabular}{|c|c|c|}
\hline GTP II clusters/priorities & Objectives of GTP II & $\begin{array}{l}\text { Agenda } 2030 \\
\text { SDGs }\end{array}$ \\
\hline \multicolumn{3}{|l|}{ Macro Economy } \\
\hline \multirow{2}{*}{$\begin{array}{l}\text { Economic growth and poverty } \\
\text { reduction }\end{array}$} & Reduce poverty by Sustaining double digit economic growth & $\begin{array}{c}1.1,1.2,2.1,8.1 \\
\text { and } 10.1\end{array}$ \\
\hline & Sustaining the broad-based double-digit economic growth & $\begin{array}{l}1.1,2.3,8.1,9.2 \text { and } \\
17.11\end{array}$ \\
\hline \multirow{2}{*}{ Economic structural transformation } & $\begin{array}{l}\text { ensure economic structural transformation by increasing the share of merchandize trade } \\
\text { and manufacturing industry in total GDP }\end{array}$ & 2.3, 9.2 and 17.11 \\
\hline & $\begin{array}{l}\text { Improve the capacity of micro and small-scale industries so that they could contribute to } \\
\text { economic growth and structural transformation }\end{array}$ & 8.3 and 9.3 \\
\hline \multirow{6}{*}{ Stable macro-economy } & $\begin{array}{c}\text { Increase domestic revenue by improving the tax administration System; Increasing } \\
\text { domestic saving and investment by designing new saving schemes }\end{array}$ & $\begin{array}{l}17.1,17.2,17.3 \text { and } \\
17.5\end{array}$ \\
\hline & Poverty and growth targeted public expenditure & $1.1,1.2$ and 10.4 \\
\hline & Improving the livelihood of the poor & $1.3,1.5$, and 10.4 \\
\hline & Increasing factor productively and employment by sustaining the economic growth & 8.5 and 8.6 \\
\hline & Increasing the service and accessibility of financial institutions & 8.10 \\
\hline & Ensure stable macro economy with integrated monitory and fiscal policy & 3 \\
\hline \multicolumn{3}{|l|}{$\begin{array}{c}\text { Rural development and food } \\
\text { security }\end{array}$} \\
\hline \multirow{13}{*}{$\begin{array}{l}\text { Agricultural Development and } \\
\text { Rural Transformation }\end{array}$} & Ensure food security by increasing crop productivity & $2.1,2.3,8.1,17.11$ \\
\hline & Increasing the productivity of crop & $2.1,2.3,8.1,17.11$ \\
\hline & Increasing the access of agriculture extension Service & $2.1 ; 2.2 ; 2.3 ; 2.4$ \\
\hline & Increasing agricultural inputs utilization & $2.1 ; 2.2 ; 2.3 ; 2.4$ \\
\hline & Expansion of agricultural mechanization & $2.3 ; 2.4 ; 8.2$ \\
\hline & Cooperative development and capacity building & $2 ; 8$ \\
\hline & Increasing horticultural investment & $2.1 ; 2.4 ; 3.9 ; 17.5 ; 17.11$ \\
\hline & $\begin{array}{c}\text { Expansion of medium and large-scale commercial farms and increasing their production } \\
\text { and productivity }\end{array}$ & $2 ; 17.5 ; 17.11$ \\
\hline & Plant protection and quality improvement & $2.3 ; 2.4$ \\
\hline & $\begin{array}{c}\text { Promoting climate-resilience agriculture through implementation of best agricultural } \\
\text { practices }\end{array}$ & $2.4 ; 13.1 ; 13.2$ \\
\hline & $\begin{array}{l}\text { Enhancing the contribution of livestock in food security by sustainably increasing the } \\
\text { sector's production and productivity }\end{array}$ & $2.1 ; 2.2 ; 2.3 ; 8.1$ \\
\hline & Increasing investment in livestock sector & $2 ; 8.1 ; 17.5$ \\
\hline & Genetic improvement of local livestock breeds & 2.3 \\
\hline
\end{tabular}




\begin{tabular}{|c|c|c|}
\hline & Supply of improved livestock feed & 2.3 \\
\hline & Establishment of rural landownership, utilization and Administration system & $1.4 ; 2.3 ; 10.2 ; 12.2$ \\
\hline & Establish rural land administration, use and coverage System & $1.4 ; 2.3 ; 10.2 ; 12.2$ \\
\hline & Capacity building on rural land administration and utilization & $2.3 ; 12.2$ \\
\hline & Sustained agricultural development by expanding watershed management practices & $2.4 ; 15.2 ; 15.3 ; 15.5 ; 15.9$ \\
\hline & Sustaining agricultural development by expanding watershed management practices & $\begin{array}{l}2.4 ; 15.2 ; 15.3 ; 15.5 \\
; 15.9\end{array}$ \\
\hline & Improve water resource management and utilization & $2.4 ; 6.5 ; 12.2 ; 15.1$ \\
\hline & Implement integrated soil fertility management system & $2.4 ; 13.1 ; 15.3$ \\
\hline & Improve biodiversity conservation and sustainable utilization based on equitable benefit & $2.4 ; 2.5 ; 15.6 ; 15.8$ \\
\hline & Strengthen disaster preparedness and response system & 1.5 \\
\hline & Ensure food security & $1.1 ; 1.2 ; 1.3 ; 2.1 ; 2.2$ \\
\hline & $\begin{array}{l}\text { Increase foreign exchange earnings contribution of the sector by strengthening the } \\
\text { agricultural marketing system }\end{array}$ & $8.1 ; 17.11$ \\
\hline \multirow{3}{*}{$\begin{array}{l}\text { Environment and climate resilient } \\
\text { green development }\end{array}$} & Strengthen climate resilient green economy & 3.9; 12.8; 13.3; and 17.3 \\
\hline & $\begin{array}{c}\text { Establish a system where environmental safety rights, forest development and protection } \\
\text { and use right would be respected and implemented }\end{array}$ & $\begin{array}{l}11.6, \\
13.3\end{array}$ \\
\hline & $\begin{array}{l}\text { Increase forest coverage through identification, demarcation, registration and protection of } \\
\text { forest lands } \\
\text { Increase ecological benefits of forest through sustainable forest protection and } \\
\text { conservation }\end{array}$ & $\begin{array}{l}12.8, \\
15.2\end{array}$ \\
\hline
\end{tabular}

Source: adapted from the GTP II conservation 
The Government of Ethiopia has implemented an agriculture-led development strategy through its Agricultural Development-led Industrialization (ADLI) policy since 1993. The ADLI strategy has been embedded in the successive policies and plans including the last one, the GTP II. National agricultural development plan is articulated in a range of strategies and policies including: the Agriculture Growth Program (AGP), the Livestock \& Fisheries Sector Plan (LFSP), the Livestock Master Plan (LMP), the Productive Safety Net Program (PSNP), the Sustainable Land Management Program (SLMP)and the Agricultural Transformation Agenda (TA).

After being the fastest growing economy in Africa for nearly a decade, Ethiopia's real GDP growth decelerated to 8\% in 2015-16 and 7.7\% in 2017-18. Unlike previous years, growth was driven by industry, mainly construction and services. Agriculture has been making a lower contribution to growth compared to the previous years. On the demand side, economic growth was driven by private consumption and public investment (World Bank, 2019). Table 2 presents the performance and targets for selected indicators of the Ethiopian economy. Comparing the objectives for the end of the GTP II (2019-20) and achievements in 2015-16, there is an important gap. Agricultural annual growth is still far below the targeted 8\% while its share in GDP is higher than planned and productivity has increased beyond its target.

Table 2: Performance and targets for selected macroeconomic indicators

\begin{tabular}{|c|c|c|}
\hline & $\begin{array}{c}\text { Base year } \\
(2015 / 2016)\end{array}$ & $\begin{array}{c}\text { Target } \\
(2019 / 2020) \\
\end{array}$ \\
\hline Average annual GDP growth rate (\%) & 8.00 & 11.00 \\
\hline Average annual Agriculture GDP (\%) & 2.30 & 8.00 \\
\hline Average Industry GDP (\%) & 20.60 & 20.00 \\
\hline Average Services GDP (\%) & 8.70 & 10.00 \\
\hline Share of agriculture to overall GDP growth rate (\%) & 36.70 & 33.50 \\
\hline Share of industry to overall GDP growth rate (\%) & 16.70 & 22.30 \\
\hline Share of manufacturing to overall GDP growth rate (\%) & 5.40 & 8.00 \\
\hline Per Capita GDP@CMP (USD) & 794.00 & 1,177 \\
\hline Export to GDP ratio (\%) & 8.00 & 20.60 \\
\hline Import to GDP ratio (\%) & 27.80 & 32.30 \\
\hline Trade Balance (\%) & 19.80 & 11.70 \\
\hline Domestic saving to GDP (\%) & 22.40 & 29.60 \\
\hline Investment to GDP (\%) & 38.50 & 41.30 \\
\hline Total revenue to GDP (\%) & 16.00 & 17.60 \\
\hline Tax to GDP ratio (\%) & 12.50 & 17.20 \\
\hline Total Expenditure as share GDP (\%) & 18.40 & 22.60 \\
\hline Deficit to GDP ratio (\%) & 2.40 & $>3$ \\
\hline Capital expenditure to GDP (\%) & 9.40 & 13.40 \\
\hline Poverty-oriented Expenditure as share of GDP (\%) & 12.10 & 15.40 \\
\hline Urban unemployment (\%) & 16.90 & 12.20 \\
\hline Population living below the poverty (\%) & 23.50 & 16.70 \\
\hline Agricultural Productivity of Major crops (quintals/ha) & 21.37 & 17.30 \\
\hline
\end{tabular}

Source: Growth and Transformation Plan II (GTP II) report ,2016 
According to AU/NEPAD (2003), CAADP is Africa's policy framework for agricultural transformation, wealth creation, food security and nutrition, economic growth and prosperity for all. It was adopted in Maputo in 2003 by the African heads of states and government. CAADP had four pillars: Pillar 1: Sustainable land and water management; Pillar 2: Improved rural infrastructure and trade related capacities for market access; Pillar 3: Increasing food supply and reducing hunger and Pillar 4: Agricultural research, technology dissemination and adoption.

In 2014, the AU heads of states and government evaluated the achievements of CAADP in the first 10 years of implementation (2003-2013) and also identified areas that need to be strengthened to realize the aspirations of CAADP. They then adopted the Malabo Declaration on CAADP which is a statement that entails further commitments on pursuing the goals of CAADP. The Malabo Declaration was adopted in 2014 with seven priority areas or commitment areas, (AU/NEPAD (2014)): Retain the principles and values of the CAADP process, Enhance investment finance in agriculture, end hunger in Africa by 2025 by accelerating agricultural growth by at least doubling current agricultural productivity levels, by the year 2025 and by integrating measures for increased agricultural productivity with social protection initiatives focusing on vulnerable social groups. The fourth commitment is to half poverty by the year 2025, through inclusive agricultural growth and transformation to ensure that the agricultural growth and transformation process is inclusive and contributes at least $50 \%$ to the overall poverty reduction target, to sustain annual agricultural GDP growth of at least 6\%, to establish and/or strengthen inclusive public-private partnerships for at least five priority agricultural commodity value chains with strong linkages to smallholder agriculture and to create job opportunities for at least $30 \%$ of the youth in agricultural value chains. The fifth commitment is to boost intra-African trade in agricultural commodities and services by tripling intra-Africa trade in agricultural commodities and fast tracking continental free trade area and transition to a continental common external tariff scheme. The sixth and seven commitments are, respectively, to enhance resilience in livelihoods and production systems to climate variability and other shock and mutual accountability to actions and results. The current study will address progress made by Ethiopia towards four commitments that the methodology utilized can measure. Table 3 presents these four commitments and the indicator used as a metric of performance and the target. While most targets can be assessed as compared to a predetermined target, some are expected to increase $(>)$ or decrease $(<)$. 
Table 3: Selected CAADP Malabo Commitments and Goals

\begin{tabular}{|c|c|c|}
\hline Goal & Indicator & Target \\
\hline \multicolumn{3}{|c|}{ Commitment to Enhancing Investment Finance in Agriculture (II) } \\
\hline \multirow{2}{*}{$\begin{array}{l}\text { Enhance investment finance, both public } \\
\text { and private, to agriculture }\end{array}$} & $\begin{array}{c}\text { Share of Government agriculture expenditures in total } \\
\text { Government expenditures (\%) }\end{array}$ & 10 \\
\hline & Private investment in agriculture, variation (\%) & $>$ \\
\hline \multicolumn{3}{|c|}{ Commitment to Ending Hunger in Africa by 2025 (III) } \\
\hline End extreme poverty and hunger & $\begin{array}{c}\text { Extreme poverty level, at the national food poverty line, } \\
\text { variation (\%) }\end{array}$ & -95 \\
\hline \multirow{2}{*}{$\begin{array}{l}\text { Increase agricultural productivity and } \\
\text { production levels }\end{array}$} & $\begin{array}{l}\text { Growth rate of agricultural value added per agricultural } \\
\text { worker (\%) }\end{array}$ & 100 \\
\hline & $\begin{array}{c}\text { Growth rate of agricultural value added per hectare of } \\
\text { arable land (\%) }\end{array}$ & 100 \\
\hline $\begin{array}{l}\text { Halve the current levels of Post-Harvest } \\
\text { Losses, by the year } 2025\end{array}$ & $\begin{array}{c}\text { Growth rate of agricultural post-production value added per } \\
\text { worker (\%) }\end{array}$ & 50 \\
\hline \multirow{2}{*}{$\begin{array}{l}\text { Integrate measures for increased } \\
\text { agricultural productivity with social } \\
\text { protection initiatives }\end{array}$} & Gini coefficient, variation (\%) & $<$ \\
\hline & $\begin{array}{c}\text { Share of the poorest } 40 \% \text { quintile in food expenditures, } \\
\text { variation (\%) }\end{array}$ & $>$ \\
\hline \multicolumn{3}{|c|}{$\begin{array}{c}\text { Commitment to halving poverty by the year 2025, through inclusive agricultural growth and } \\
\text { transformation (IV) }\end{array}$} \\
\hline \multirow{2}{*}{$\begin{array}{l}\text { Increased economic opportunities and } \\
\text { reduced poverty levels }\end{array}$} & Poverty level, at the national poverty line, variation (\%) & -50 \\
\hline & $\begin{array}{c}\text { Household final consumption expenditure per capita at } \\
\text { constant } 2010 \text { local currency, variation (\%) }\end{array}$ & $>$ \\
\hline \multirow{2}{*}{$\begin{array}{l}\text { Ensure agricultural-led growth and } \\
\text { poverty reduction target }\end{array}$} & Agricultural GDP, annual variation (\%) & 6 \\
\hline & Agricultural contribution to GDP growth (\%) & 50 \\
\hline \multicolumn{3}{|c|}{ Commitment to Boosting Intra-African Trade in Agricultural Commodities (V) } \\
\hline $\begin{array}{l}\text { Increased intra-African regional trade } \\
\text { and better functioning of national \& } \\
\text { regional markets }\end{array}$ & $\begin{array}{l}\text { Growth rate of the value of agricultural commodities traded } \\
\text { with Africa, in constant values (\%) }\end{array}$ & 200 \\
\hline
\end{tabular}

Part of the SDGs' vision includes a world free of poverty, hunger, and where food is sufficient, safe, affordable and nutritious, where every country enjoys sustained, inclusive and sustainable economic growth and decent work for all (United Nations 2015). It is grounded in the Universal Declaration of Human Rights, international human rights treaties, the Millennium Declaration and the 2005 World Summit Outcome Declaration on the Right to Development. Specific goals of interest are the following: Goal 1. End poverty in all its forms everywhere; Goal 2. End hunger, achieve food security and improved nutrition and promote sustainable agriculture; Goal 8. Promote sustained, inclusive and sustainable economic growth, full and productive employment and decent work for all and Goal 10. Reduce inequality within and among countries.

Regarding poverty reduction, Ethiopia has achieved important results on the Millennium Development Goals (MDGs). In 2015/16, 27 percent of Ethiopians lived below the international poverty line (US\$1.9 per capita per day, 2011 purchasing power parity) compared to 34 percent in 2010/11. The country is also a signatory to the Sustainable Development Goals (SDGs) with the objective of achieving a set of common goals that meet urgent global environmental, economic and political challenges by 2030. Among the 
seventeen SDGs considered by the United Nations Agenda, the agricultural sector is concerned by or is expected to have a direct contribution to following five goals (Table 4).

Table 4: Selected SDGs

\begin{tabular}{|c|c|c|}
\hline Result & Indicators & Target \\
\hline \multicolumn{3}{|c|}{ Halving poverty (Goal 1) } \\
\hline Eradicate extreme poverty & $\begin{array}{l}\text { Proportion of population below the international } \\
\text { poverty line of } \$ 1.25 \text { a day PPP }\end{array}$ & -95 \\
\hline $\begin{array}{l}\text { Reduce at least by half the proportion of } \\
\text { population living in poverty }\end{array}$ & $\begin{array}{l}\text { Proportion of population living below the national } \\
\text { poverty line }\end{array}$ & -50 \\
\hline $\begin{array}{l}\text { Implement nationally appropriate social } \\
\text { protection systems and measures }\end{array}$ & $\begin{array}{c}\text { Proportion of population covered by social protection } \\
\text { floors/systems }\end{array}$ & $>$ \\
\hline \multicolumn{3}{|c|}{ End hunger (Goal 2) } \\
\hline $\begin{array}{l}\text { End hunger and ensure access to safe, } \\
\text { nutritious and sufficient food }\end{array}$ & $\begin{array}{c}\text { Poverty level at national food poverty line (Prevalence } \\
\text { of undernourishment if data available) }\end{array}$ & -95 \\
\hline \multirow{2}{*}{$\begin{array}{l}\text { Double the agricultural productivity and } \\
\text { incomes of small-scale food producers }\end{array}$} & Volume of agricultural production per labor & 100 \\
\hline & Average income of food producers & 100 \\
\hline \multicolumn{3}{|c|}{ Promote sustained, inclusive and sustainable economic growth (Goal 8) } \\
\hline \multirow{3}{*}{ Sustain per capita economic growth } & Annual growth rate of real GDP per capita & $>$ \\
\hline & Annual growth rate of real GDP & 7 \\
\hline & Annual growth rate of real GDP per employed person & $>$ \\
\hline \multirow{2}{*}{$\begin{array}{l}\text { Achieve full and productive employment } \\
\text { and decent work }\end{array}$} & Average hourly earnings & $>$ \\
\hline & Unemployment rate & $<5$ \\
\hline \multicolumn{3}{|c|}{ Promote inclusive and sustainable industrialization (Goal 9) } \\
\hline \multirow{2}{*}{$\begin{array}{l}\text { Promote inclusive and sustainable } \\
\text { industrialization }\end{array}$} & $\begin{array}{l}\text { Manufacturing value added as a proportion of GDP and } \\
\text { per capita }\end{array}$ & 100 \\
\hline & $\begin{array}{c}\text { Manufacturing employment as a proportion of total } \\
\text { employment }\end{array}$ & 100 \\
\hline \multicolumn{3}{|c|}{ Reduce inequality within and among countries (Goal 10) } \\
\hline $\begin{array}{l}\text { Achieve and sustain income growth of the } \\
\text { bottom } 40 \text { per cent of the population }\end{array}$ & $\begin{array}{c}\text { Growth rates of household expenditure or } \\
\text { income per capita among the bottom } 40 \text { per cent of the } \\
\text { population and the total population }\end{array}$ & $>$ \\
\hline $\begin{array}{l}\text { Adopt policies, especially fiscal, wage and } \\
\text { social protection policies, and } \\
\text { progressively achieve greater equality }\end{array}$ & Labor earning share of GDP & $>$ \\
\hline
\end{tabular}

The Vision for the Africa Agenda 2063 was adopted in March 2013 by the African Union Commission (AUC). The first implementation of the plan runs between 2013 and 2023. The Agenda 2063 is a strategic framework for the socio-economic transformation of the continent over the next 50 years. It builds on and seeks to accelerate the implementation of past and existing continental initiatives for growth and sustainable development. Some of the main characteristics and intensions of the Agenda 2063 include, the creation and maintenance of an effective-equitable and people-centered growth and development, the eradication of poverty, and enabling internal coherence and coordination to continental, regional and national frameworks and plans adopted by the AUC, Regional Economic Communities (RECs) and member states. Some of the Africa Agenda 2063 goals which are important for this study includes: Goal 1: A high standard of living, 
quality of life and well-being for all citizens; Goal 3: Healthy and well-nourished citizens and Goal 5: Modern agriculture for increased productivity and production.

An important issue is whether Ethiopia's vision and goals are coherent with its continental agricultural sectorwide commitments and goals as set out in the CAADP Malabo, SDGS and Agenda 2063 commitments and goals. As discussed above, each of the commitments have goals, some similar, others different. In some cases, the agendas specify a numeric target, while in others the target is simply an increase or decrease in the value of an indicator. These targets are used in assessing whether the country would be able to attain the goals set out in the different commitments.

\section{Methods and data}

An economic modeling framework is built to assess the strategic options available to Ethiopia to accelerate growth and reduce poverty as envisaged by the GTP II and committed under the Malabo Agenda and UN SDGs. The framework consists of an economywide general equilibrium model and a microsimulation model. The two models are linked in a sequential manner, that is, the output from one model is used as an input by the other model. Indeed, as suggested by Fofana et al. (2019), a mix of economic models is necessary to properly address multiple goals carried by the agricultural development agendas. Thus, the macroeconomic model addresses the growth and investment goals and targets. However, the latter does not include issues related to inequality and poverty which are better handled in the microeconomic model. The macroeconomic model is an agricultural investment focused computable general equilibrium (CGE) model grounded in the Walrasian small open economy framework. The microeconomic model is a statistical economic model built to capture income distribution among the population. Changes in the probabilities associated with individual income levels induced by changes in mean (per capita) income are assessed through a "generalized entropy” measure (Lee and Judge, 1996). Further details about key characteristics of the micro and macro models are available in Fofana et al. (2019). ${ }^{2}$ The following sections focus on salient features of Ethiopia's macro and micro databases used to calibrate the models.

The Household Income Consumption and Expenditure (2015-2016 HCE) conducted by the Ethiopia Central Statistical Agency (CSA) is used to implement the microeconomic model. The HCE is part of household surveys series and is used as the main official data source for tracking poverty and welfare, informing the policy makers and informing the desig and implementation of a series of poverty reduction strategies and programs and subsequently national development programs and plans such as the Second Growth and Transformation Plan (2015/16 - 2019/20). The 2015-16 HCE survey covered all rural and urban areas of

\footnotetext{
${ }^{2}$ Fofana, I., Omolo, M., Goundan, A., Domgho, L., Collins, J. and Marti, E.. 2019. NAIP toolkit for Malabo domestication: Economic modeling of agricultural growth and investment strategy, case study of Kenya. IFPRI Discussion Paper 01813. Washington DC.
} 
the country. A stratified random sampling technique was employed to draw a representative sample of 30,255 households in urban and rural areas of the country. The country was first stratified into nine regional states and two city administrations. Each regional state was further stratified into three broad categories namely, rural, major urban centers and other urban area categories.

The CGE model is implemented using a Social Accounting Matrix (SAM). A SAM is a square matrix that describes the transaction flows taking place within an economy during a given period of time (Fofana et al. 2015). The CGE model is implemented using the 2011 SAM for Ethiopia (Ahmed et al. 2017). The SAM describes 70 industries (or commodities), including 25 agricultural industries (or commodities); 11 food processing, tobacco and beverages industries and 28 other industries (or commodities); 13 accounts for factors; and 18 institutional accounts, including 1 account for the rest of the world.

\section{Results}

The business as usual (BaU) scenario projects the Ethiopian economy over the period 2011-2024 based on its performance between 2011 and 2015 and between 2016 and 2019 (Table 5 and 6). While Table 5 presents the benchmark data used to calibrate GDP and major macroeconomic indicators, Table 6 is used to calibrate major socio economic variables.

Table 5: Ethiopia's Selected Economic Variables, Trend and Outlook 2011-2024

\begin{tabular}{|c|c|c|c|c|}
\hline Subject Descriptor & Units & $\mathbf{2 0 1 1 - 2 0 1 5}$ & $\mathbf{2 0 1 6 - 2 0 1 9}$ & $\mathbf{2 0 2 0 - 2 0 2 4}$ \\
\hline Gross domestic product, constant prices & Percent change & 10.1 & 8.4 & 7.1 \\
\hline Total investment & Percent of GDP & 36.1 & 38.4 & 36.9 \\
\hline Gross national savings & Percent of GDP & 31.1 & 31.1 & 32.9 \\
\hline Volume of imports of goods and services & Percent change & 16.0 & 3.1 & 3.8 \\
\hline Volume of exports of goods and services & Percent change & 3.2 & 10.3 & 8.7 \\
\hline General government revenue & Percent of GDP & 15.6 & 14.4 & 13.2 \\
\hline General government total expenditure & Percent of GDP & 17.5 & 17.3 & 16.0 \\
\hline Current account balance & Percent of GDP & -6.5 & -7.6 & -4.0 \\
\hline
\end{tabular}

Source: World Economic Outlook (IMF, 2019) 
Table 6: Ethiopia's Selected Socioeconomic Variables, Trend 2011-2018

\begin{tabular}{|c|c|c|}
\hline Subject Descriptor & $\mathbf{2 0 1 1 - 2 0 1 5}$ & $\mathbf{2 0 1 6}-\mathbf{2 0 1 8}$ \\
\hline Households and NPISHs Final consumption expenditure (annual \% growth) & 7.5 & 7.6 \\
\hline GDP growth (annual \%) & 10.2 & 8.6 \\
\hline Agriculture, forestry, and fishing, value added (annual \% growth) & 6.6 & 4.7 \\
\hline Industry (including construction), value added (annual \% growth) & 19.1 & 18.8 \\
\hline Manufacturing, value added (annual \% growth) & 14.6 & 17.7 \\
\hline Services, value added (annual \% growth) & 11.2 & 9.2 \\
\hline Population growth (annual \%) & 2.8 & 2.7 \\
\hline labor force, (annual \% growth) & 3.7 & 3.6 \\
\hline Employment, (annual \% growth) & 3.7 & 3.6 \\
\hline Rural population growth (annual \%) & 2.3 & 2.1 \\
\hline Urban population growth (annual \%) & 5.1 & 4.9 \\
\hline Government Capital Expenditure, average Annual growth* & 25.0 & 17 \\
\hline Government Capital Expenditure, \%GDP* & 10.0 & 8.9 \\
\hline ( & 9.0 & 8.2 \\
\hline
\end{tabular}

Source: World Development Indicators (World Bank, 2019); * African Statistical Yearbook (AfDB; UNECA and AUC, 2019);

** ReSAKSS Database (ReSAKSS, 2019).

Under the BaU scenario, Ethiopia would make insufficient progress towards meeting much of the CAADP commitments and objectives although the country meets the goal of increasing private agricultural investment and agricultural post-production productivity (Table 7). Agricultural productivity remains far behind CAADP targets. Although Ethiopia had met the CAADP target of allocating at least $10 \%$ of public investment in earlier years, investment has been below targeted levels on average since 2011 (Table 7). Improving agricultural performance would contribute to progress towards the overall objectives of increasing income, reducing income inequality and reducing poverty. However, it would be insufficient to achieve the CAADP goal of halving poverty between 2015 and 2025. Growth and the contribution of the agricultural sector to the creation of economic wealth would still be below the CAADP target and below the performance of the sector until 2025. Production and consumption of locally produced food would contribute significantly to reducing hunger. In the BaU scenario, little progress is made in this area. Under the BaU, Ethiopia would increase its agricultural and agri-food trade with both its non-African and African partners. However, Ethiopia would not be on track to achieve the CAADP goal of tripling intra-African agricultural trade under the $\mathrm{BaU}$. 
Table 7: Progress towards Selected CAADP Goals, BaU Scenario (Percent Cumulative 2015-2025)

\begin{tabular}{|c|c|c|c|c|}
\hline Goal & Result & Metric & $\begin{array}{c}\text { BaU } \\
\text { Progress }\end{array}$ & $\begin{array}{l}\text { CAADP } \\
\text { Target }\end{array}$ \\
\hline \multirow{2}{*}{$\begin{array}{l}\text { Increase Agriculture } \\
\text { Investment }\end{array}$} & $\begin{array}{l}\text { Increase Agricultural } \\
\text { Public Investment }\end{array}$ & $\begin{array}{l}\text { Public Agricultural Investment, } \\
\text { Share of Total Public Investment }\end{array}$ & 8.2 & 10.0 \\
\hline & $\begin{array}{c}\text { Increase Agricultural } \\
\text { Private Investment }\end{array}$ & Private Agricultural Investment & 208.7 & $>$ \\
\hline \multirow{8}{*}{ End Hunger } & \multirow{3}{*}{$\begin{array}{l}\text { Increase Agricultural } \\
\text { Productivity }\end{array}$} & $\begin{array}{c}\text { Total Factor Productivity } \\
\text { Agriculture } \\
\end{array}$ & 10.6 & 100.0 \\
\hline & & Agricultural Land Productivity & 56.3 & 100.0 \\
\hline & & Agricultural Labor Productivity & 2.6 & 100.0 \\
\hline & \multirow{2}{*}{$\begin{array}{l}\text { Increase Agricultural } \\
\text { Post-Production } \\
\text { Productivity }\end{array}$} & $\begin{array}{c}\text { Total Factor Productivity, } \\
\text { Domestic Trade } \\
\end{array}$ & 86.8 & 50.0 \\
\hline & & $\begin{array}{c}\text { Total Factor Productivity, Food } \\
\text { Industries }\end{array}$ & 69.4 & 50.0 \\
\hline & $\begin{array}{l}\text { Increase Consumption of } \\
\text { Locally Produced Food }\end{array}$ & $\begin{array}{l}\text { Consumption Locally Produced } \\
\text { Food, Ratio Total Food } \\
\text { Consumption }\end{array}$ & 1.1 & $>$ \\
\hline & $\begin{array}{l}\text { Reduce income } \\
\text { inequality }\end{array}$ & $\begin{array}{c}\text { Share Poorest Quintile to Total } \\
\text { Consumption Expenditure }\end{array}$ & 5.1 & $>$ \\
\hline & $\begin{array}{l}\text { Reduction Extreme } \\
\text { Income Poverty }\end{array}$ & $\begin{array}{c}\text { Poverty Headcount Index, Food } \\
\text { poverty line, Change (\%) }\end{array}$ & -24.0 & -95.0 \\
\hline \multirow{3}{*}{ Halve Poverty } & $\begin{array}{c}\text { Accelerate Agricultural } \\
\text { Growth }\end{array}$ & Agricultural GDP, Annual Growth & 4.8 & 6.0 \\
\hline & $\begin{array}{c}\text { Achieve Agriculture-led } \\
\text { Poverty Reduction }\end{array}$ & $\begin{array}{c}\text { Agricultural contribution to GDP } \\
\text { Growth }\end{array}$ & 21.1 & 50.0 \\
\hline & $\begin{array}{c}\text { Reduction Income } \\
\text { Poverty } \\
\end{array}$ & $\begin{array}{l}\text { Poverty Headcount Index, National } \\
\text { poverty line }\end{array}$ & -19.5 & -50.0 \\
\hline $\begin{array}{l}\text { Boost Intra-African } \\
\text { Agricultural Trade }\end{array}$ & $\begin{array}{l}\text { Increase Intra-Africa } \\
\text { Agricultural Trade }\end{array}$ & $\begin{array}{c}\text { Intra-Africa Imports and Exports } \\
\text { of Agricultural and Food } \\
\text { Commodities }\end{array}$ & 44.5 & 200.0 \\
\hline
\end{tabular}

Source: Simulation Results.

Note: Unless otherwise noted, values shown are cumulative growth rates from 2015 to 2025. Values for “Agricultural Share

Public Investment” and “Agriculture Contribution to GDP Growth” denote average annual shares. Values for "Agricultural GDP, Annual” refer to average annual growth rates.

Green indicates that the goal is met (>90\%); yellow indicates that much progress is made toward the goal ( $>50 \%$ and $90 \%)$; orange indicates that little progress is made toward the goal ( $>10 \%$ and $50 \%)$; red indicates that very little progress is made toward the goal ( $10 \%$ or less); grey indicates that data are not available to assess the progress towards the target. For directional goals, i.e. goals without numeric target, the progress is assessed against the initial value.

Under the BaU scenario, we find that three of the five goals considered in this analysis are fully or partially met: end hunger, sustainable economic growth and inclusive and sustainable industrialization (Table 8). Concerning halving poverty, the country achieves one third of the target for the international poverty line and half of the poverty reduction objective measured by the national poverty line. The country would also not be on track to meet the inequality reduction goals by 2030. Indeed, the latest household survey showed a slight increase in inequality compared to previous periods between rural and urban households (HCE 2015-16). 
Table 8: Progress towards Selected SDGs, BaU Scenario (Percent Cumulative 2015-2030)

\begin{tabular}{|c|c|c|c|c|}
\hline Goals & Result & Metric & $\begin{array}{c}\text { BaU } \\
\text { Progress }\end{array}$ & $\begin{array}{c}\text { SDGs } \\
\text { Target }\end{array}$ \\
\hline \multirow{2}{*}{$\begin{array}{l}\text { Halving poverty } \\
\text { (Goal 1) }\end{array}$} & Eradicate extreme poverty & $\begin{array}{l}\text { Proportion of population below } \\
\text { the international poverty line of } \\
\$ 1.90 \text { a day PPP }\end{array}$ & -31.9 & -95.0 \\
\hline & $\begin{array}{l}\text { Reduce at least by half the } \\
\text { proportion of population } \\
\text { living in poverty }\end{array}$ & $\begin{array}{l}\text { Proportion of population living } \\
\text { below the national poverty line }\end{array}$ & -25.6 & -50.0 \\
\hline \multirow{2}{*}{ End hunger (Goal 2) } & \multirow{2}{*}{$\begin{array}{l}\text { Double the agricultural } \\
\text { productivity and incomes of } \\
\text { small-scale food producers }\end{array}$} & $\begin{array}{c}\text { Volume of agricultural production } \\
\text { per labor }\end{array}$ & 87.2 & 100.0 \\
\hline & & $\begin{array}{c}\text { Average income of food } \\
\text { producers }\end{array}$ & 249.2 & 100.0 \\
\hline \multirow{5}{*}{$\begin{array}{l}\text { Sustainable } \\
\text { economic growth } \\
\text { (SDG 8) }\end{array}$} & \multirow{3}{*}{$\begin{array}{l}\text { Sustain per capita economic } \\
\text { growth }\end{array}$} & $\begin{array}{c}\text { Annual growth rate of real GDP } \\
\text { per capita }\end{array}$ & 125.4 & $>$ \\
\hline & & Annual growth rate of real GDP & 8.4 & 7.0 \\
\hline & & $\begin{array}{c}\text { Annual growth rate of real GDP } \\
\text { per employed person }\end{array}$ & 75.1 & $>$ \\
\hline & \multirow{2}{*}{$\begin{array}{l}\text { Achieve full and productive } \\
\text { employment and decent work }\end{array}$} & Average hourly earnings & 314.4 & $>$ \\
\hline & & Unemployment rate, change & 0.2 & $<6$ \\
\hline \multirow{2}{*}{$\begin{array}{c}\text { Inclusive and } \\
\text { sustainable } \\
\text { industrialization } \\
\text { (SDG 9) } \\
\end{array}$} & \multirow{2}{*}{$\begin{array}{c}\text { Promote inclusive and } \\
\text { sustainable industrialization }\end{array}$} & $\begin{array}{l}\text { Manufacturing value added as a } \\
\text { proportion of GDP and per capita }\end{array}$ & 172.0 & 100.0 \\
\hline & & $\begin{array}{l}\text { Manufacturing employment as a } \\
\text { proportion of total employment }\end{array}$ & 30.7 & 100.0 \\
\hline \multirow[b]{2}{*}{$\begin{array}{l}\text { Reduce inequality } \\
\text { (SDG 10) }\end{array}$} & Reduce income inequality & $\begin{array}{c}\text { Share Poorest Quintile to Total } \\
\text { Consumption Expenditure }\end{array}$ & 7.0 & $>$ \\
\hline & $\begin{array}{l}\text { Adopt policies, especially } \\
\text { fiscal, wage and social } \\
\text { protection policies, and } \\
\text { progressively achieve greater } \\
\text { equality }\end{array}$ & Labor earning share of GDP & 10.7 & $>$ \\
\hline
\end{tabular}

Source: Simulation Results

Note: Unless otherwise noted, values shown are cumulative growth rates from 2015 to 2030. Values for “GDP, Annual Growth” refer to average annual growth rates. Values for "Unemployment rate” are reported for the specific year, i.e. they are not cumulative.

Green indicates that the goal is met (>90\%); yellow indicates that much progress is made toward the goal ( $>50 \%$ and $90 \%)$; orange indicates that little progress is made toward the goal ( $>10 \%$ and $50 \%)$; red indicates that very little progress is made toward the goal ( $10 \%$ or less); grey indicates that data are not available to assess the progress towards the target. For directional goals, i.e. goals without numeric target, the progress is assessed against the initial value.

In the BaU scenario, we find mixed results for the objectives of the Agenda 2063. Ethiopia would be on track to meet two out of the four goals of the Agenda 2063 presented in Table 9. That is Incomes, jobs and decent work and Sustainable and inclusive economic growth. The Agenda 2063 goal on poverty, inequality and hunger will not be met under the BaU scenario despite an increase in per capita income. Inequality reduction measured by rural-to-urban income ratio shows no progress in the baseline as inequality is increasing. Other poverty reduction goals show little progress. Similarly, the BaU scenario gives little progress on agricultural productivity and production. 
Table 9: Progress towards Selected Goals of Agenda 2063, BaU Scenario (Percent Cumulative 20152035)

\begin{tabular}{|c|c|c|c|c|}
\hline Goal & Result & Metric & BaU Progress & $\begin{array}{c}\text { Agenda } \\
2063 \\
\text { Target }\end{array}$ \\
\hline \multirow{4}{*}{$\begin{array}{l}\text { Poverty, } \\
\text { inequality and } \\
\text { hunger }\end{array}$} & \multirow[t]{2}{*}{ Poverty Reduction } & $\begin{array}{c}\text { Proportion of population below the } \\
\text { international poverty line of } \$ 1.90 \text { a day } \\
\text { PPP }\end{array}$ & -43.1 & -95.0 \\
\hline & & $\begin{array}{l}\text { Proportion of population living below } \\
\text { the national poverty line }\end{array}$ & -35.2 & -95.0 \\
\hline & Hunger Eradication & Food Import Dependency Ratio & -36.5 & -70.0 \\
\hline & Inequality Reduction & Rural-to-Urban Income Ratio & -29.4 & 50.0 \\
\hline \multirow{2}{*}{$\begin{array}{l}\text { Incomes, jobs } \\
\text { and decent } \\
\text { work }\end{array}$} & \multirow{2}{*}{$\begin{array}{l}\text { Employment and } \\
\text { Incomes }\end{array}$} & Unemployment Rate & 0.0 & 6.0 \\
\hline & & Per Capita Income Growth & 229.4 & $>$ \\
\hline \multirow{2}{*}{$\begin{array}{l}\text { Sustainable } \\
\text { and inclusive } \\
\text { economic } \\
\text { growth }\end{array}$} & $\begin{array}{l}\text { Inclusive Economic } \\
\text { Growth }\end{array}$ & GDP, Annual Growth & 8.4 & 7.0 \\
\hline & Intra-African Trade & Value of intra-Africa Trade & 285.5 & 120.0 \\
\hline $\begin{array}{l}\text { Agricultural } \\
\text { productivity } \\
\text { and production }\end{array}$ & Productivity Growth & Agricultural TFP & 22.4 & 500.0 \\
\hline
\end{tabular}

Source: Simulation Results

Note: Unless otherwise noted, values shown are cumulative changes from 2015 to 2035. Values for “GDP, Annual Growth” refer to average annual growth rates. Values for "Unemployment rate" are reported for the specific year, i.e. they are not cumulative. Green indicates that the goal is met (>90\%); yellow indicates that much progress is made toward the goal ( $>50 \%$ and $90 \%)$; orange indicates that little progress is made toward the goal (>10\% and $50 \%$ ); red indicates that very little progress is made toward the goal (10\% or less); grey indicates that data are not available to assess the progress towards the target. For directional goals, i.e. goals without numeric target, the progress is assessed against the initial value.

The previous section showed that Ethiopia would make progress towards the achievement of some objectives set by the CAADP, the SDGs and Agenda 2063. However, other development objectives would not be achieved under the BaU scenario. Alternative options for accelerated agricultural growth and transformation would be needed to attain more goals set by the three agendas. The following sections presents the results from a simulation of the national agricultural investment scenario (NAIS).

The acceleration of agricultural growth and transformation as called for by the Malabo Declaration requires public financing to improve the competitiveness of the sector and the achievement of the sector's development objectives. In this context, it is important to ensure the judicious allocation of investments, including their distribution among the different sectors of the economy and along the agricultural value chain. In addition, in the context of resource scarcity, adequate options for financing the required public investments are needed. Figure 1 shows the effect of a 1 percent increase in public investment allocation to the agricultural sector compared to non-agricultural sectors, i.e. industry and services. In these simulations, public investment increases are financed by external resources - foreign loans, international development assistance, and other external sources. Other options for financing public investments are explored in the 
next section. Increasing agricultural public investment would accelerate overall GDP and improve income and food consumption in Ethiopia. It appears that agricultural growth is more inclusive than nonagricultural growth. In other words, the resulting growth in income and food consumption is significantly larger for agricultural investments compared to non-agricultural investments. The positive effect of agricultural investment on overall GDP is higher than that of industry and higher than that of services. Thus, increasing agricultural public investment is better for Ethiopia in terms of income growth and distribution and, ultimately, poverty reduction and the elimination of hunger.

Figure 1: Growth and Poverty Effects of a 1 Percent Point Increase in Public Investment by Economic Sector, Percent Point Change from Baseline

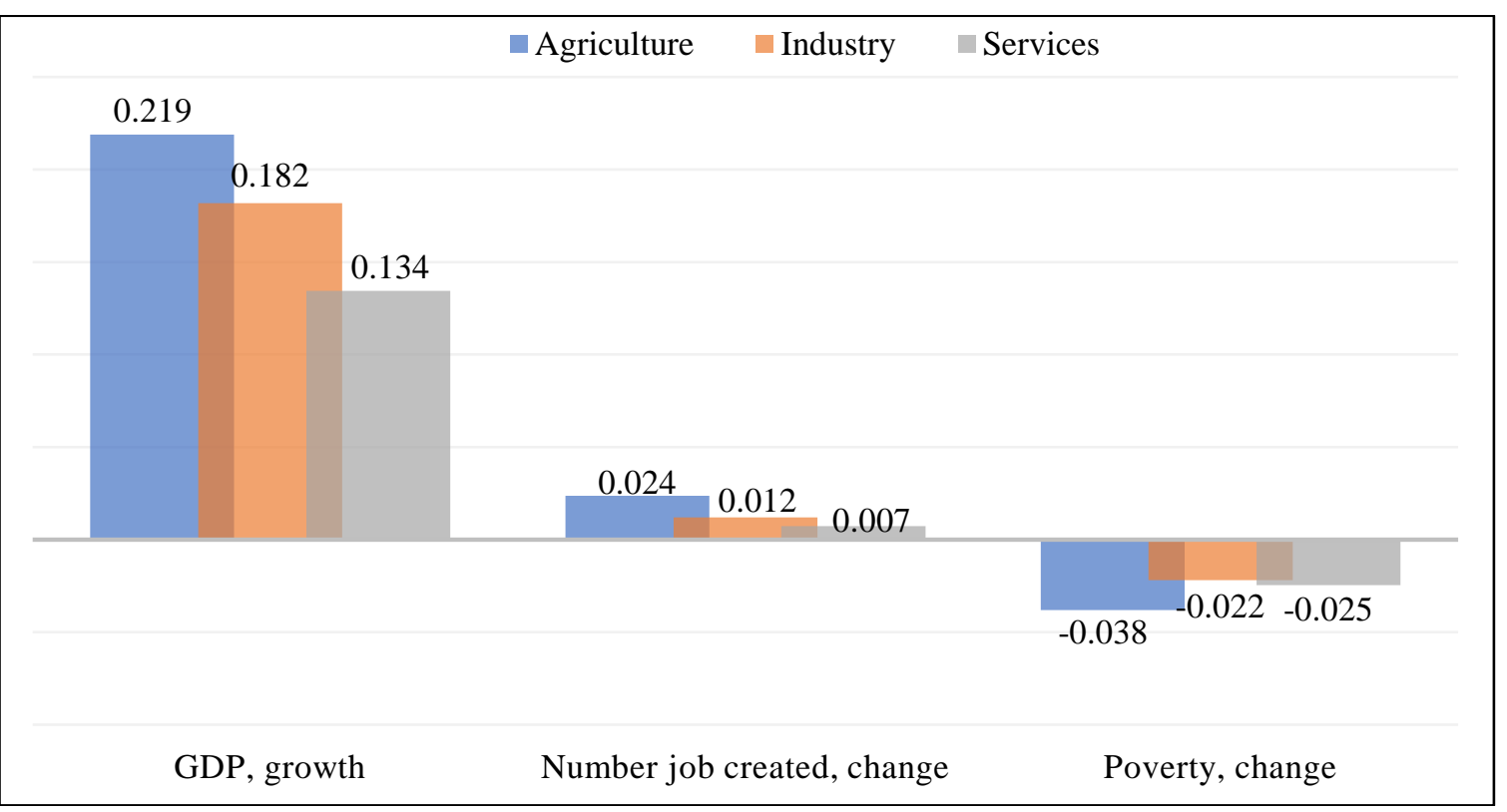

Source: Simulation results.

Note: Under external financing option.

Irrespective of the financing options, agricultural investment has a positive impact on economic growth and poverty reduction compared to $\mathrm{BaU}$; external funding exhibits the highest return. Figure 2 presents the impact of alternative agriculture and rural development investment financing options to accelerate agricultural growth and economic transformation. Specifically, three options for agricultural investment financing are compared: Revenue neutral assumes fixed total investment expenditures; thus, an increase in investment in one sector requires a decrease in other sectors; Budget neutral assumes that increases in investment expenditures are funded through increased tax revenues from households' income and properties (direct tax); External financing assumes that increases in investment expenditures are funded externally, i.e. through international borrowing or development assistance. 
Figure 2 shows that external financing of investments allows for the highest impact in terms of economic growth and poverty reduction. While external financing exhibits the best outcomes, it is worth noting the positive outcomes of investing in agriculture compared to BaU irrespective of the financing options.

Figure 2: Growth and Poverty Effects of a 1 Percent Point Increase in Public Investment by Financing Option, Percent Point Change from Baseline

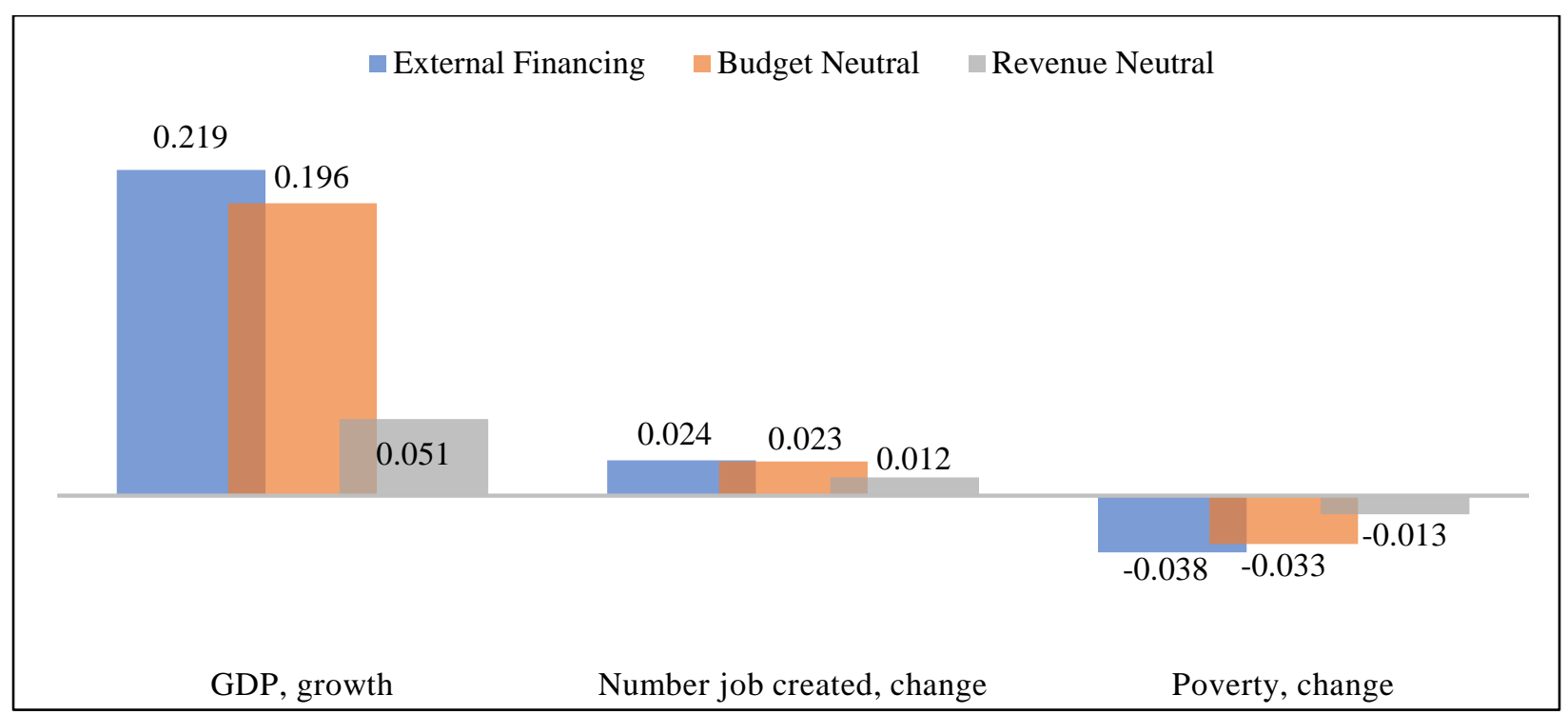

Source: Simulation Results

Across the agricultural sub-sectors, agricultural public investment is found to be more effective in the crops sub-sector for the attainment of the CAADP goals followed by fishery. For the Agenda 2063 while fishery yields higher scores, crops, livestock and forestry are found to be equally effective. Regarding the SDGs, the most effective is livestock followed by forestry while crops and fishery ${ }^{3}$ give similar effectiveness scores.

\footnotetext{
${ }^{3}$ Although fishery gives a high effectiveness score, it has not been selected among the strategic agricultural commodities presented in the next section. This is in line with the characteristics of Ethiopia, a land locked country with limited water resources for developing the fishery sector.
} 
Figure 3: Public Investment Effectiveness Score by Agricultural Sub-Sector

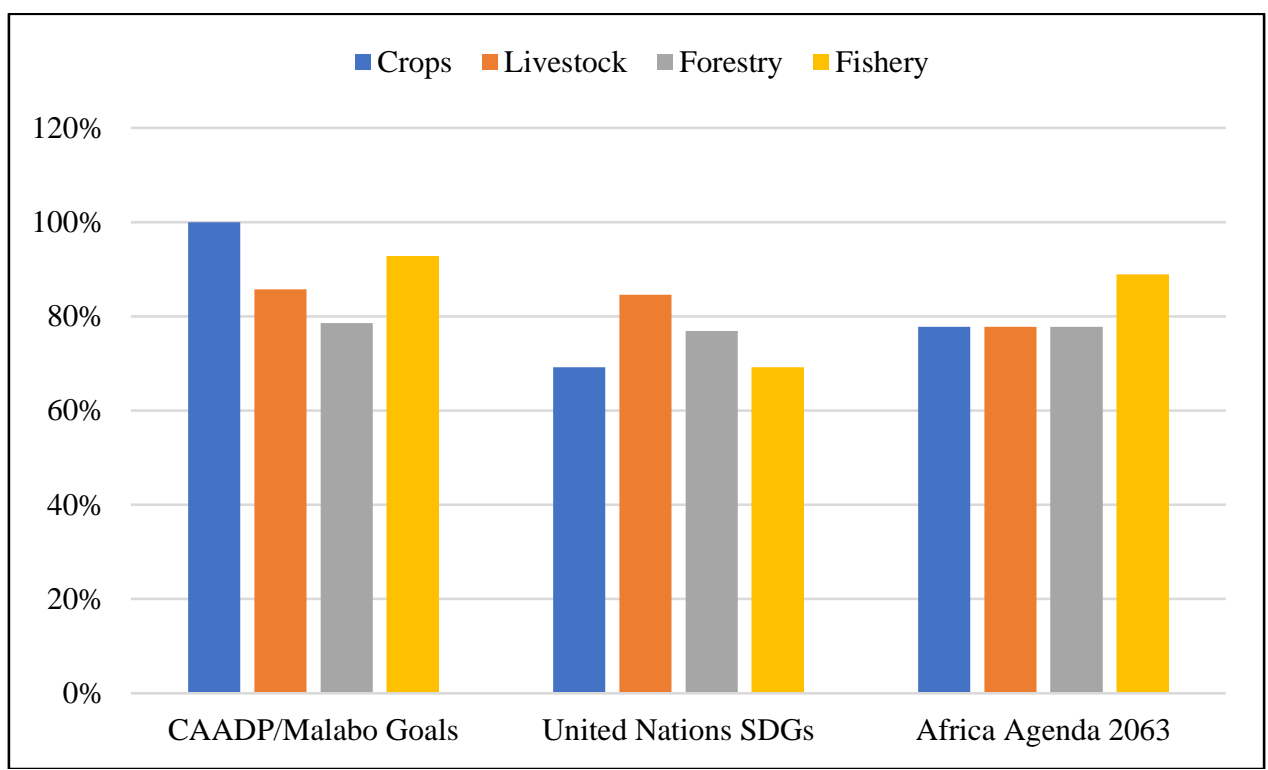

Source: Simulation results.

Note: Under External Financing Option.

The Malabo Declaration calls for the identification of priority agricultural value chains. The CGE model is used to identify priority agricultural commodities based on their contributions to agricultural GDP growth and national income growth. First, top 20 commodities are selected based on criteria listed above. Then, at least six commodities are chosen based on their rank, i.e. contribution, across the two criteria (Figure 4). These strategic commodities with the highest contribution to improving the four results are: maize, sorghum, teff, wheat, pulses, coffee, cattle, milk and sheep meat.

Figure 4: Public Investment Effectiveness Score for Selected Agricultural Commodities

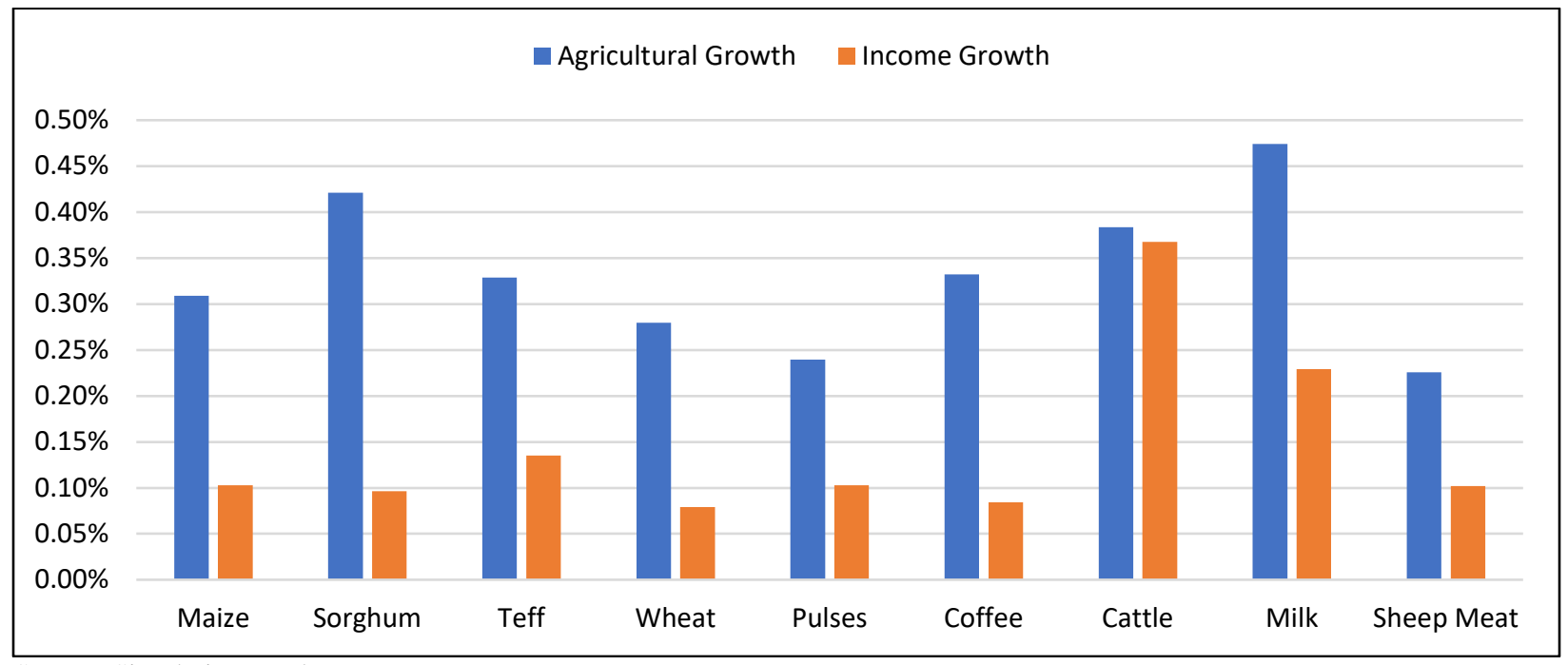

Source: Simulation results.

Note: Under External Financing Option. 
Across the agricultural value chain, several public investment options and their outcomes were analyzed. Findings are summarized in Figure 5. Increasing productivity gives the highest effectiveness score compared to other forms of public investment followed by investments in physical capital in food processing and domestic trade of food and cash transfers to poor households. Public investments allowing higher agricultural productivity (i.e. increases in technical efficiency), agroindustry productivity and productivity in food domestic trade of agricultural and processed food would enable over $85 \%$ attainment of CAADP goals while Agenda 2063 and SDGs would be attained at nearly 80\% and 70\% respectively.

Figure 5: Public Investment Effectiveness Score Along Agricultural Value Chain

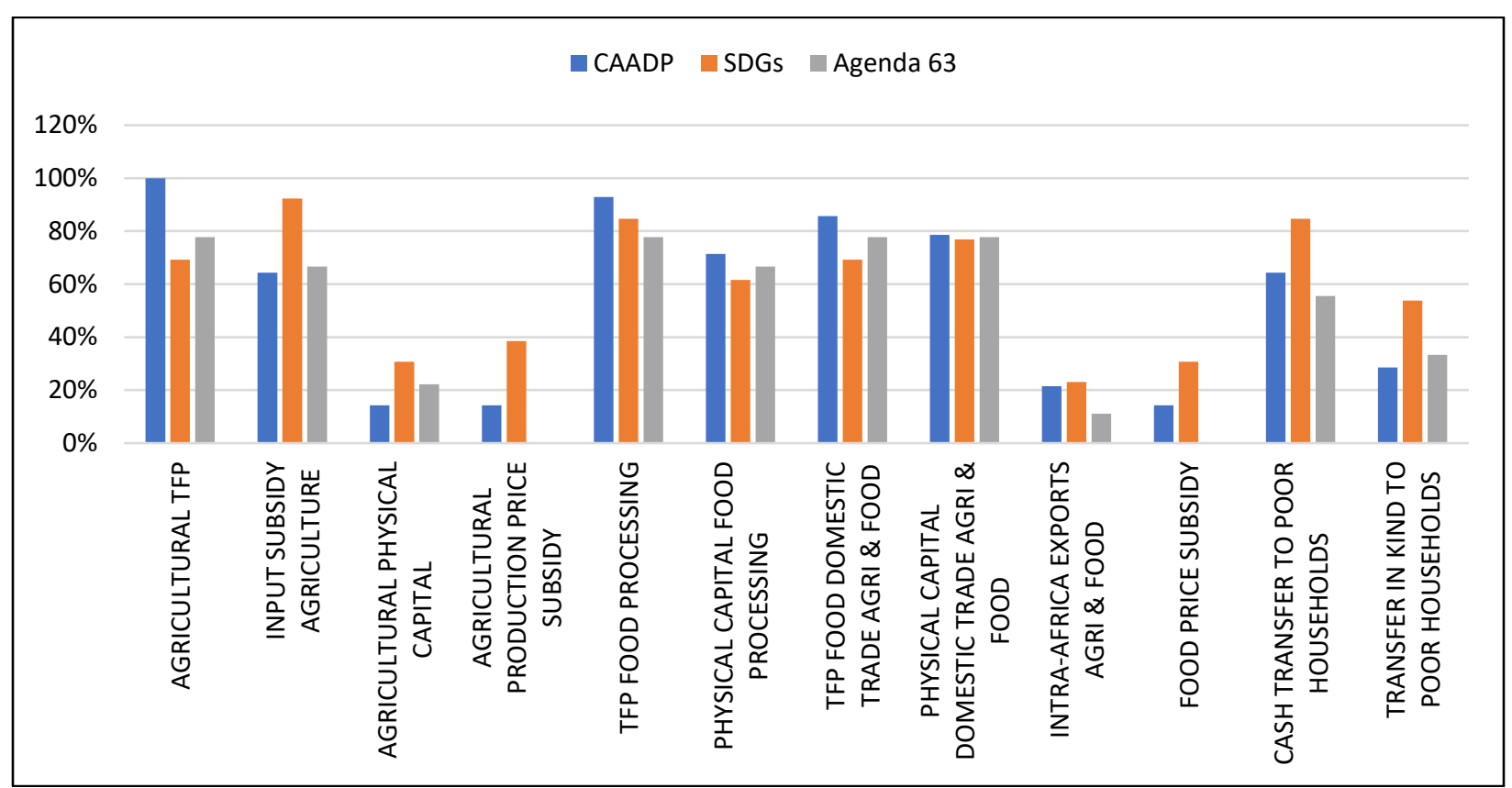

Source: Simulation results.

Note: Under External Financing Option.

Generally, the analysis reported in Figure 5 shows that supply side investments - those targeted toward production, processing and domestic trade rather than toward consumers-are more likely to contribute to the achievement of agricultural development goals. An input subsidy is most efficient in achieving the agricultural productivity growth and agricultural growth goals, as well as the goals related to local food consumption, income and food expenditure growth. The goals of boosting intra-Africa trade of agricultural commodities are better achieved through investments to improve the technical efficiency of agricultural producers. However, scaling up the supply side investments cannot be sustained without increasing the demand side, including the mid-stream investments, i.e. agroindustry and domestic trading of ag commodities; agroindustry productivity increase has a limit that is compensated by domestic trading of ag commodities. 
A priority for public agricultural investment would be to target productivity in agriculture (8.5\% share in the public investment), agroindustry (3.6\% share in the public investment) and capital subsidy in domestic trade of agricultural and food commodities (2.9\% share in the public investment) as presented in Figure 6. Additional investments appear to be critical to boosting agricultural demand and strengthening the competitiveness of the agricultural sector. Government investments should increase substantially in facilitating domestic trade and subsidizing inputs (Figure 6).

Figure 6: Public Agricultural Investment Priority Areas, Percent Point Public Investment Increase Compared to $\mathrm{BaU}$

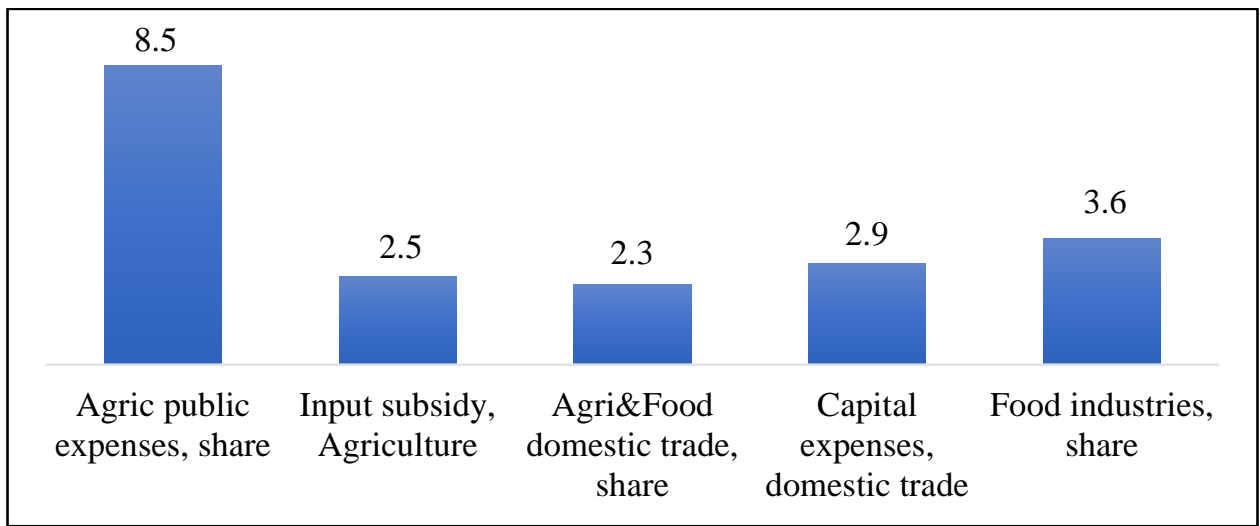

Source: Simulation Results

Public agricultural investments should increase to reach at least the $10 \%$ target set by the Malabo Declaration under the NAIS scenario. Public agricultural investments are expected to crowd in private investments under the NAIS scenario. This increase in private investments is much higher than that observed in the BaU scenario (Figure 8). While private investment in agriculture per se increases, total private investment increases more in the simulation scenario pulled by foreign investors contribution. 
Figure 7: Percent Increase in Private Investment, Annual Average

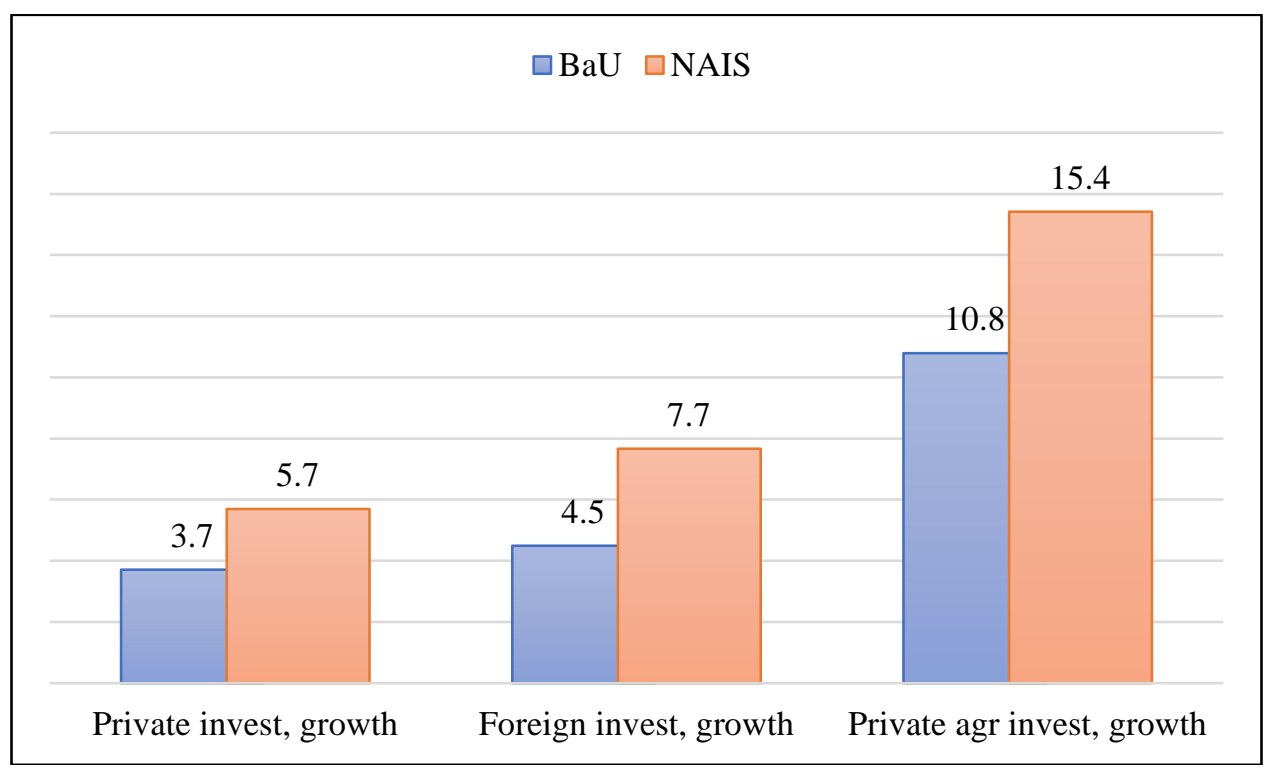

Source: Simulation Results

Under the NAIS, the cost of input use in agricultural production should decrease relative to BaU scenario (Table 10). As a result, access to agricultural inputs improves as input expenditure per hectare is projected to increase substantially. Increasing input use in agriculture should sustain the increase in agricultural productivity. The latter is projected to increase a little under the BaU but increases nearly fivefold in the NAIS scenarios. The annual growth rate of the agricultural sector would accelerate to $9.2 \%$ under the NAIS scenario compared to $4.8 \%$ under the BaU through sustained high agricultural productivity and increased market opportunities (Table 12). In the implementation of CAADP, Ethiopia should target a 11.2 percent annual increase in agricultural production in order to achieve several of the agricultural development goals. This should be supported by a strategy that increases domestic and foreign demand for agricultural products to sustain agricultural competitiveness and income growth (Table 11). For the livestock sector, an expansion of local production would lead to an import substitution and a substantial increase in exports.

Table 10: Agricultural Productivity and Production Growth, Average Annual Growth (\%)

\begin{tabular}{|c|c|c|}
\hline & BaU & NAIS \\
\hline Cost of agricultural inputs & 2.8 & -2.1 \\
\hline Intensity of input use & 5.9 & 16.7 \\
\hline Agricultural total factor productivity & 0.9 & 4.3 \\
\hline Agricultural land use & 0.7 & 0.9 \\
\hline Agricultural labor-to-land ratio & 3.9 & 4.2 \\
\hline Agricultural private capital-to-land ratio & 7.8 & 8.3 \\
\hline Agricultural Production & 5.2 & 11.2 \\
\hline
\end{tabular}

Source: Simulation Results 
At the sub-sector level, the NAIS scenario results in higher growth in the livestock sector followed by the forestry and crops sub-sectors (Figure 8).

Figure 8: Agricultural Production Growth by Agricultural Sub-sector (\%)

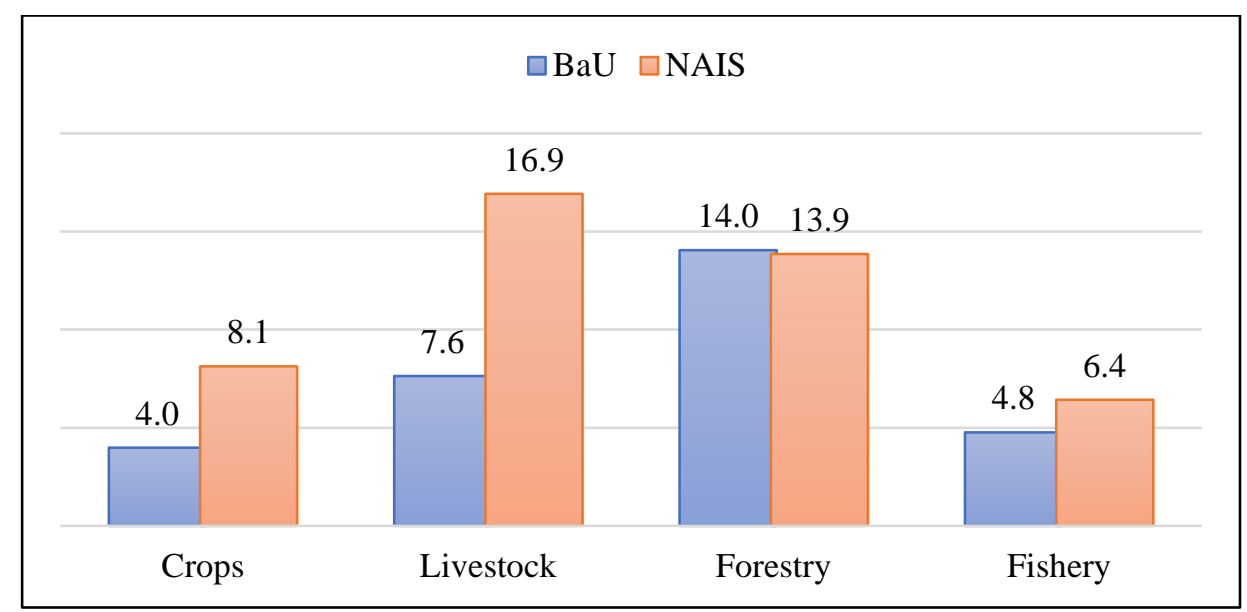

Table 11: Percent Change in Production, Exports and Imports for Selected Agricultural Commodities, NAIS Scenario, Annual Average

\begin{tabular}{|c|c|c|c|c|c|c|c|}
\hline \multirow{2}{*}{ Commodities } & \multirow{2}{*}{$\begin{array}{c}\text { Production } \\
\text { growth }\end{array}$} & \multicolumn{2}{|c|}{ Export Growth } & & \multicolumn{2}{|c|}{ Import Growth } & \\
\cline { 3 - 8 } & Total & Africa & Row & Total & Africa & Row \\
\hline Maize & 12.1 & 14.8 & 9.7 & 19.5 & 3.4 & 5.0 & 3.3 \\
\hline Sorghum & 12.0 & 13.3 & 8.8 & 17.4 & 5.7 & 6.9 & 5.7 \\
\hline Teff & 9.4 & & & & & & \\
\hline Wheat & 11.3 & 10.6 & 7.3 & 13.7 & 8.2 & 8.8 & 8.2 \\
\hline Pulses & 10.1 & 12.6 & 7.1 & 14.0 & 3.9 & 4.8 & 3.7 \\
\hline Coffee & 9.0 & 9.3 & 5.0 & 9.4 & & & \\
\hline Cattle & 20.4 & 36.1 & 17.1 & 37.0 & -2.2 & 1.0 & -2.7 \\
\hline Milk & 17.4 & & & & -6.8 & -2.9 & -7.4 \\
\hline Sheep Meat & 16.4 & 34.1 & 15.8 & 34.9 & -6.9 & -3.5 & -7.5 \\
\hline
\end{tabular}

Source: Simulation results.

Note: RoW: Rest of World.

The increase in supply is reflected by the downward pressure on consumer prices increases for food products (Figure 9). The slowing down in food prices is driven mainly by lower prices for local products as the prices of imported food products increase more and remain nearly the same in both scenarios. Increased local food production and supply is expected to reduce the country's dependence on imports. The relatively higher demand and lower prices in the NAIS scenario compared to the BaU would increase the competitiveness of agriculture and factor remuneration, and ultimately increase income and consumption in rural areas (Figure 10). 
Figure 9: Change in Food Prices, Annual Average (\%)

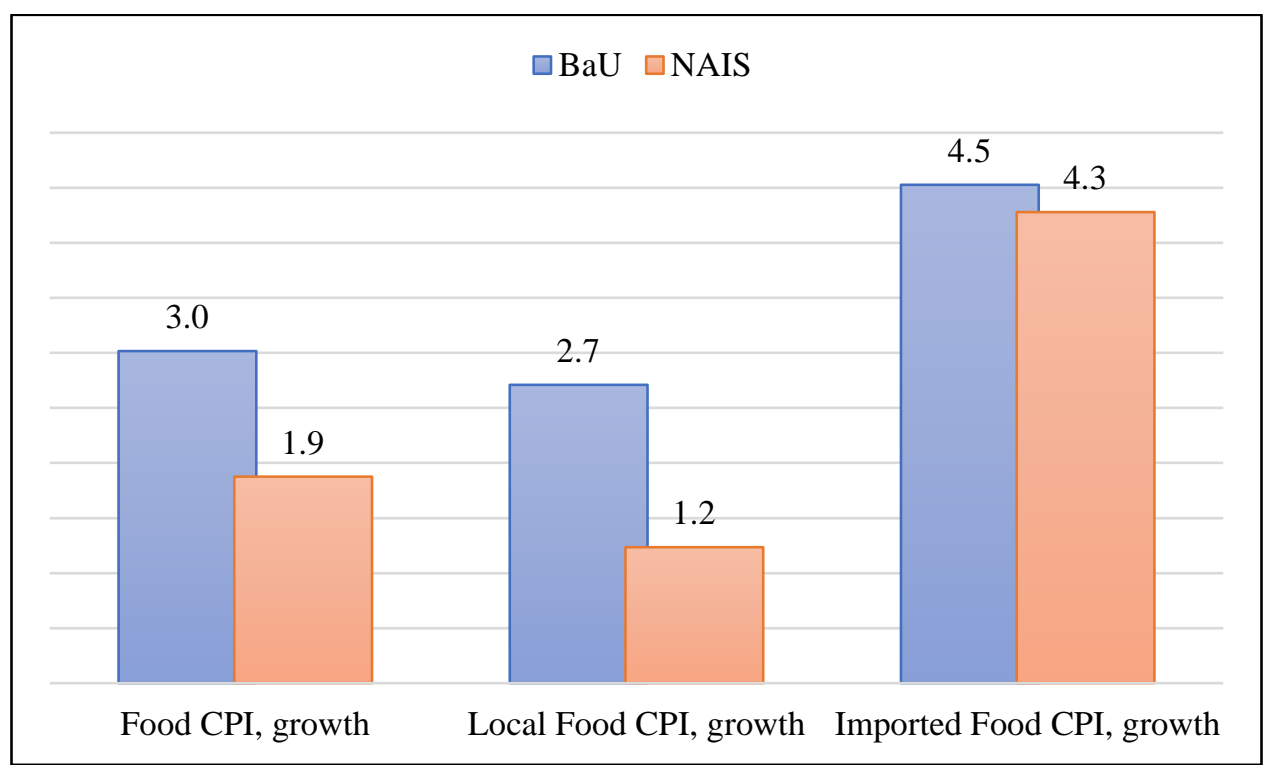

Source: Simulation Results

Note: CPI: Consumer Price Index.

Figure 10: Increase in Income and Food Consumption Expenditure, Annual Average (\%)

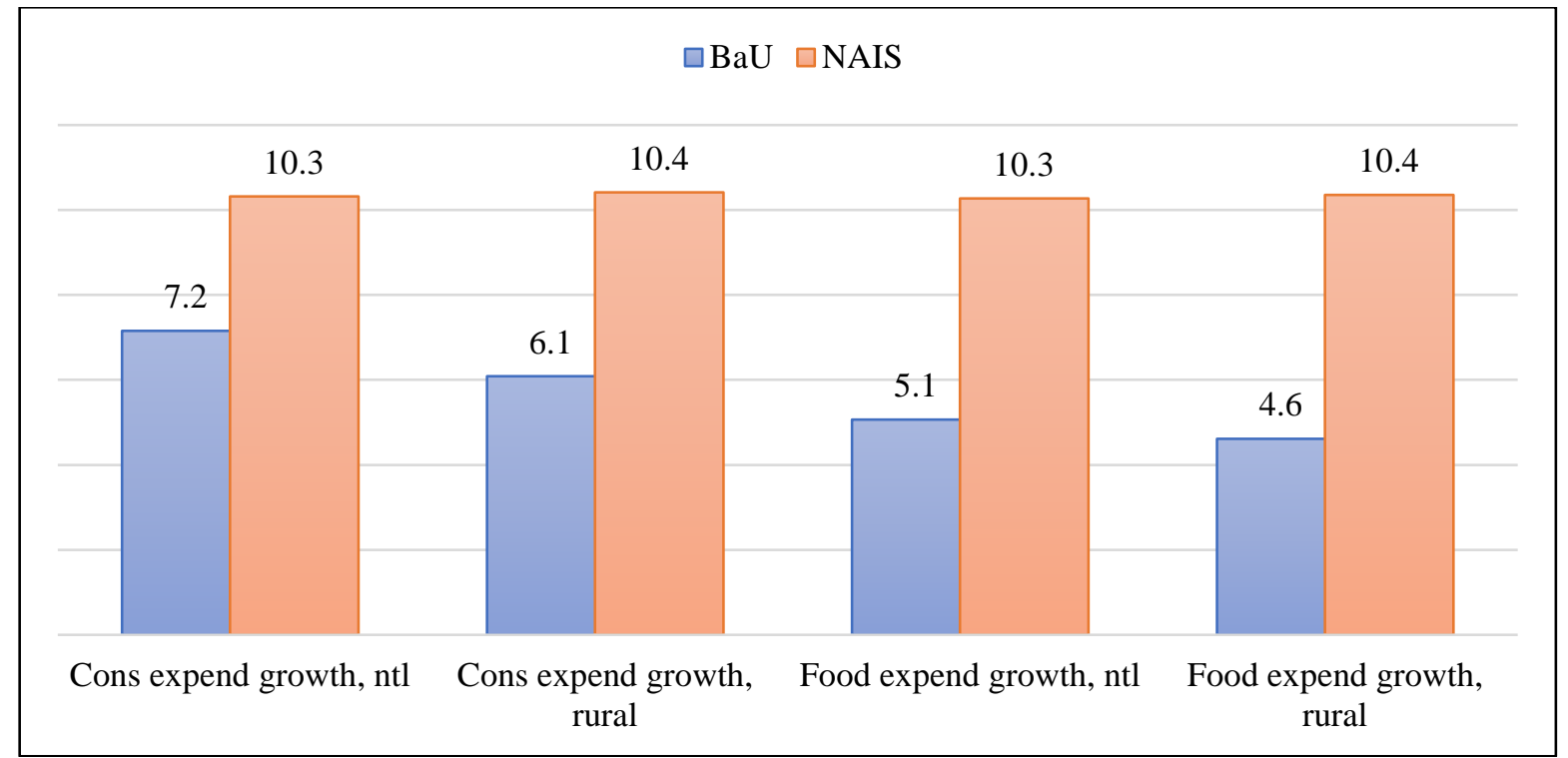

Source: Simulation Results

Under the NAIS scenario, Ethiopia would significantly improve the performance of the agricultural sector and would achieve more of the targets set by the CAADP agenda (Table 12). Beyond the objectives of agricultural productivity and production that were not achieved under the $\mathrm{BaU}$, the increase in public agricultural investments would improve the contribution of agriculture to the poverty reduction (Table 12). Agricultural growth and contribution to overall GDP would increase beyond targets but this is not enough 
to attain the objective of halving poverty and eliminating hunger by 2025. This is an indication that some targets will be difficult to achieve through increased agricultural growth alone, despite the relatively large size of the sector in Ethiopia. Ethiopia will be off track to meet the extreme poverty and hunger goal, as measured by the food poverty headcount ratio, under both the BaU and NAIS scenarios. There is little progress on the consumption of locally produced food in comparison to total food consumption. Inequality reduction is also slow as the share of the poorest quintile in total consumption expenditure does not improve notably. Stronger growth outside of the agricultural sector as well as social protection programs will be necessary to further reduce poverty and hunger.

Table 12: Progress towards Selected CAADP Goals, NAIS Scenario (Percent Cumulative 2015-2025)

\begin{tabular}{|c|c|c|c|c|c|}
\hline Goal & Result & Metric & $\begin{array}{c}\text { BaU } \\
\text { Progress }\end{array}$ & $\begin{array}{l}\text { NAIS } \\
\text { Progress }\end{array}$ & $\begin{array}{c}\text { CAADP } \\
\text { Target }\end{array}$ \\
\hline \multirow{2}{*}{$\begin{array}{l}\text { Increase } \\
\text { Agriculture } \\
\text { Investment }\end{array}$} & $\begin{array}{l}\text { Increase Agricultural } \\
\text { Public Investment }\end{array}$ & $\begin{array}{l}\text { Public Agricultural Investment, } \\
\text { Share of Total Public Investment }\end{array}$ & 8.2 & 16.7 & 10.0 \\
\hline & $\begin{array}{l}\text { Increase Agricultural } \\
\text { Private Investment }\end{array}$ & Private Agricultural Investment & 208.7 & 384.2 & $>$ \\
\hline \multirow{8}{*}{ End Hunger } & \multirow{3}{*}{$\begin{array}{l}\text { Increase Agricultural } \\
\text { Productivity }\end{array}$} & $\begin{array}{c}\text { Total Factor Productivity } \\
\text { Agriculture }\end{array}$ & 10.6 & 58.2 & 100.0 \\
\hline & & Agricultural Land Productivity & 56.3 & 136.5 & 100.0 \\
\hline & & Agricultural Labor Productivity & 2.6 & 50.2 & 100.0 \\
\hline & \multirow{2}{*}{$\begin{array}{l}\text { Increase Agricultural } \\
\text { Post-Production } \\
\text { Productivity }\end{array}$} & $\begin{array}{c}\text { Total Factor Productivity, } \\
\text { Domestic Trade }\end{array}$ & 86.8 & 166.7 & 50.0 \\
\hline & & $\begin{array}{c}\text { Total Factor Productivity, Food } \\
\text { Industries }\end{array}$ & 69.4 & 1152.5 & 50.0 \\
\hline & $\begin{array}{c}\text { Increase Consumption } \\
\text { of Locally Produced } \\
\text { Food }\end{array}$ & $\begin{array}{c}\text { Consumption Locally Produced } \\
\text { Food, Ratio Total Food } \\
\text { Consumption } \\
\end{array}$ & 1.1 & 2.8 & $>$ \\
\hline & $\begin{array}{c}\text { Reduce income } \\
\text { inequality }\end{array}$ & $\begin{array}{l}\text { Share Poorest Quintile to Total } \\
\text { Consumption Expenditure }\end{array}$ & 5.1 & 16.7 & $>$ \\
\hline & $\begin{array}{l}\text { Reduction Extreme } \\
\text { Income Poverty }\end{array}$ & $\begin{array}{l}\text { Poverty Headcount Index, Food } \\
\text { poverty line, Change (\%) }\end{array}$ & -24.0 & -28.0 & -95.0 \\
\hline \multirow{3}{*}{ Halve Poverty } & $\begin{array}{l}\text { Accelerate Agricultural } \\
\text { Growth } \\
\end{array}$ & $\begin{array}{l}\text { Agricultural GDP, Annual } \\
\text { Growth }\end{array}$ & 4.8 & 9.2 & 6.0 \\
\hline & $\begin{array}{l}\text { Achieve Agriculture- } \\
\text { led Poverty Reduction }\end{array}$ & $\begin{array}{l}\text { Agricultural contribution to GDP } \\
\text { Growth }\end{array}$ & 21.1 & 29.4 & 50.0 \\
\hline & $\begin{array}{l}\text { Reduction Income } \\
\text { Poverty }\end{array}$ & $\begin{array}{l}\text { Poverty Headcount Index, } \\
\text { National poverty line }\end{array}$ & -19.5 & -23.6 & -50.0 \\
\hline $\begin{array}{l}\text { Boost Intra- } \\
\text { African } \\
\text { Agricultural } \\
\text { Trade } \\
\end{array}$ & $\begin{array}{l}\text { Increase Intra-Africa } \\
\text { Agricultural Trade }\end{array}$ & $\begin{array}{l}\text { Intra-Africa Imports and Exports } \\
\text { of Agricultural and Food } \\
\text { Commodities }\end{array}$ & 44.5 & 64.5 & 200.0 \\
\hline
\end{tabular}

Source: Simulation Results.

Note: Unless otherwise noted, values shown are cumulative growth rates from 2015 to 2025. Values for "Agricultural Share Public Investment” and “Agriculture Contribution to GDP Growth” denote average annual shares. Values for “Agricultural GDP, Annual” refer to average annual growth rates.

Green indicates that the goal is met (> 90\%); yellow indicates that much progress is made toward the goal ( $>50 \%$ and $90 \%$ ); orange indicates that little progress is made toward the goal ( $>10 \%$ and $50 \%)$; red indicates that very little progress is made toward the goal ( $10 \%$ or less); grey indicates that data are not available to assess the progress towards the target. For directional goals, i.e. goals without numeric target, the progress is assessed against the initial value. 
In line with the results on the CAADP goals, the NAIS scenario is not enough to achieve two of the five SDGs considered in Table 13 and allows the country to make modest progress toward meeting the poverty and inequality reduction goals. Ethiopia will still be off track in halving poverty. Poverty measured by the national poverty line and by the international line of $\$ 1.90$ a day PPP show a five-percentage point reduction. Despite the importance of agriculture to Ethiopia as presented in the introduction, developments outside of the agricultural sector-in particular, increased rural nonagricultural growth and social protection-will be critical to further reducing poverty. The least progress is registered for Hoal 10 . Promoting inclusive and sustainable industrialization goal measured by the share of manufacturing in employment in total employment is not met and declines with the NAIS reflecting the still high concentration of the labor force in the agricultural sector. 
Table 13: Progress towards Selected SDGs, NAIS Scenario (Percent Cumulative 2015-2030)

\begin{tabular}{|c|c|c|c|c|c|}
\hline Goals & Result & Metric & $\begin{array}{c}\text { BaU } \\
\text { Progress } \\
\end{array}$ & $\begin{array}{c}\text { NAIS } \\
\text { Progress } \\
\end{array}$ & $\begin{array}{c}\text { SDGs } \\
\text { Target }\end{array}$ \\
\hline \multirow[b]{2}{*}{$\begin{array}{l}\text { Halving poverty } \\
\qquad \text { (Goal 1) }\end{array}$} & $\begin{array}{l}\text { Eradicate extreme } \\
\text { poverty }\end{array}$ & $\begin{array}{l}\text { Proportion of population below } \\
\text { the international poverty line of } \\
\$ 1.90 \text { a day PPP }\end{array}$ & -31.9 & -36.8 & -95.0 \\
\hline & $\begin{array}{c}\text { Reduce at least by half } \\
\text { the proportion of } \\
\text { population living in } \\
\text { poverty }\end{array}$ & $\begin{array}{l}\text { Proportion of population living } \\
\text { below the national poverty line }\end{array}$ & -25.6 & -30.7 & -50.0 \\
\hline \multirow{2}{*}{$\begin{array}{l}\text { End hunger } \\
\text { (Goal 2) }\end{array}$} & \multirow{2}{*}{$\begin{array}{l}\text { Double the agricultural } \\
\text { productivity and } \\
\text { incomes of small-scale } \\
\text { food producers }\end{array}$} & $\begin{array}{l}\text { Volume of agricultural } \\
\text { production per labor }\end{array}$ & 87.2 & 390.4 & 100.0 \\
\hline & & $\begin{array}{l}\text { Average income of food } \\
\text { producers }\end{array}$ & 249.2 & 510.5 & 100.0 \\
\hline \multirow{5}{*}{$\begin{array}{c}\text { Sustainable } \\
\text { economic } \\
\text { growth (SDG 8) }\end{array}$} & \multirow{3}{*}{$\begin{array}{l}\text { Sustain per capita } \\
\text { economic growth }\end{array}$} & $\begin{array}{l}\text { Annual growth rate of real GDP } \\
\text { per capita }\end{array}$ & 125.4 & 240.7 & $>$ \\
\hline & & Annual growth rate of real GDP & 8.4 & 11.4 & 7.0 \\
\hline & & $\begin{array}{c}\text { Annual growth rate of real GDP } \\
\text { per employed person }\end{array}$ & 75.1 & 157.0 & $>$ \\
\hline & \multirow{2}{*}{$\begin{array}{c}\text { Achieve full and } \\
\text { productive employment } \\
\text { and decent work }\end{array}$} & Average hourly earnings & 314.4 & 538.8 & $>$ \\
\hline & & Unemployment rate, change & 0.2 & 0.0 & $<6$ \\
\hline \multirow{2}{*}{$\begin{array}{c}\text { Inclusive and } \\
\text { sustainable } \\
\text { industrialization } \\
\text { (SDG 9) } \\
\end{array}$} & \multirow{2}{*}{$\begin{array}{c}\text { Promote inclusive and } \\
\text { sustainable } \\
\text { industrialization }\end{array}$} & $\begin{array}{l}\text { Manufacturing value added as a } \\
\text { proportion of GDP and per capita }\end{array}$ & 172.0 & 1003.1 & 100.0 \\
\hline & & $\begin{array}{l}\text { Manufacturing employment as a } \\
\text { proportion of total employment }\end{array}$ & 30.7 & 15.1 & 100.0 \\
\hline \multirow[b]{2}{*}{$\begin{array}{l}\text { Reduce } \\
\text { inequality } \\
\text { (SDG 10) }\end{array}$} & $\begin{array}{c}\text { Reduce income } \\
\text { inequality }\end{array}$ & $\begin{array}{c}\text { Share Poorest Quintile to Total } \\
\text { Consumption Expenditure }\end{array}$ & 7.0 & 23.4 & $>$ \\
\hline & $\begin{array}{c}\text { Adopt policies, } \\
\text { especially fiscal, wage } \\
\text { and social protection } \\
\text { policies, and } \\
\text { progressively achieve } \\
\text { greater equality }\end{array}$ & Labor earning share of GDP & 10.7 & 11.4 & $>$ \\
\hline
\end{tabular}

Source: Simulation Results

Note: Unless otherwise noted, values shown are cumulative growth rates from 2015 to 2030. Values for “GDP, Annual Growth” refer to average annual growth rates. Values for "Unemployment rate" are reported for the specific year, i.e. they are not cumulative.

Green indicates that the goal is met (> 90\%); yellow indicates that much progress is made toward the goal ( $>50 \%$ and $90 \%)$; orange indicates that little progress is made toward the goal (>10\% and $50 \%$ ); red indicates that very little progress is made toward the goal ( $10 \%$ or less); grey indicates that data are not available to assess the progress towards the target. For directional goals, i.e. goals without numeric target, the progress is assessed against the initial value.

On the targets set in the Agenda 2063, the NAIS contributes to accelerating progress but does not allow attainment of any of the objectives that were not already attained in the BaU scenario (Table 14). On the goal pertaining to poverty, inequality and hunger, Ethiopia would be achieving around $50 \%$ of the poverty reduction target but attains hunger eradication as measured by the food import dependency ratio. Inequality increases in the BaU but declines in the NAIS scenarios. Concerning agricultural productivity and production, the NAIS scenario allows to attain one third of the target only. 
Table 14: Progress towards Selected Objectives of Agenda 2063, NAIS Scenario (Percent Cumulative 2015-2025)

\begin{tabular}{|c|c|c|c|c|c|}
\hline Goal & Result & Metric & $\begin{array}{c}\text { BaU } \\
\text { Progress }\end{array}$ & $\begin{array}{l}\text { NAIS } \\
\text { Progress }\end{array}$ & $\begin{array}{l}\text { Agenda } \\
2063 \text { Target }\end{array}$ \\
\hline \multirow{4}{*}{$\begin{array}{c}\text { Poverty, } \\
\text { inequality and } \\
\text { hunger }\end{array}$} & \multirow{2}{*}{ Poverty Reduction } & $\begin{array}{l}\text { Proportion of population below } \\
\text { the international poverty line of } \\
\$ 1.90 \text { a day PPP }\end{array}$ & -43.1 & -49.0 & -95.0 \\
\hline & & $\begin{array}{l}\text { Proportion of population living } \\
\text { below the national poverty line }\end{array}$ & -35.2 & -41.6 & -95.0 \\
\hline & Hunger Eradication & Food Import Dependency Ratio & -36.5 & -70.5 & -70.0 \\
\hline & $\begin{array}{l}\text { Inequality } \\
\text { Reduction }\end{array}$ & Rural-to-Urban Income Ratio & -29.4 & 33.0 & 50.0 \\
\hline \multirow{2}{*}{$\begin{array}{l}\text { Incomes, jobs } \\
\text { and decent work }\end{array}$} & \multirow{2}{*}{$\begin{array}{l}\text { Employment and } \\
\text { Incomes }\end{array}$} & Unemployment Rate & 0.0 & 0.0 & 6.0 \\
\hline & & Per Capita Income Growth & 229.4 & 503.7 & $>$ \\
\hline \multirow{2}{*}{$\begin{array}{l}\text { Sustainable and } \\
\text { inclusive } \\
\text { economic growth }\end{array}$} & $\begin{array}{c}\text { Inclusive } \\
\text { Economic Growth }\end{array}$ & GDP, Annual Growth & 8.4 & 11.4 & 7.0 \\
\hline & Intra-African Trade & Value of intra-Africa Trade & 285.5 & 429.2 & 120.0 \\
\hline $\begin{array}{l}\text { Agricultural } \\
\text { productivity and } \\
\text { production }\end{array}$ & $\begin{array}{l}\text { Productivity } \\
\text { Growth }\end{array}$ & Agricultural TFP & 22.4 & 150.4 & 500.0 \\
\hline
\end{tabular}

Source: Simulation Results

Note: Unless otherwise noted, values shown are cumulative changes from 2015 to 2035. Values for "GDP, Annual Growth" refer to average annual growth rates. Values for "Unemployment rate" are reported for the specific year, i.e. they are not cumulative. Green indicates that the goal is met (> 90\%); yellow indicates that much progress is made toward the goal ( $>50 \%$ and $90 \%)$; orange indicates that little progress is made toward the goal ( $>10 \%$ and $50 \%$ ); red indicates that very little progress is made toward the goal ( $10 \%$ or less); grey indicates that data are not available to assess the progress towards the target. For directional goals, i.e. goals without numeric target, the progress is assessed against the initial value.

\section{Conclusion}

The 2014 Malabo Declaration on Accelerated Growth and Transformation for Shared Prosperity and Improved Livelihoods upheld the original Maputo commitment of achieving a 6\% annual agricultural growth rate and a $10 \%$ agricultural expenditure share. In addition to this agenda, Ethiopia pledged to the Agenda 2063 as well as the SDGs, which are committed to accelerating economic growth, eradicating poverty and inequality, among several other goals. However, a key challenge to implementing these commitments is the fact that they involve a large number of obligations and goals.

To address the CAADP/Malabo, the SDGs and the Agenda 2063 goals, a Results Framework 2015-2025; 2016-2030; and 2014-2035, respectively, has been developed as a key tool for translating Ethiopia's agricultural agenda into tangible outcomes. An economic modelling framework is built to assess the strategic options available to Ethiopia to accelerate growth and reduce poverty as envisaged by the MGDS III and committed under the Malabo Agenda, Agenda 2063 and SDGs. The framework consists of an economy-wide general equilibrium model and a microsimulation model. The two models are linked in a sequential manner. Thus, using these models, the paper is able to assess progress of both macro and micro variables of interest. 
The BaU scenario shows that Ethiopia is off-track to meet CAADP targets although the country meets the goal of increasing private agricultural investment and agricultural post-production productivity. Agricultural productivity and poverty reduction are below the targets set in the CAADP agenda. Production and consumption of locally produced food could contribute significantly to reducing hunger but remain low. Trade related goals with both African and non-African partners would also not be achieved. Concerning the SDGs, Ethiopia would fully or partially meet three of the five goals considered in this analysis: end hunger, sustainable economic growth and inclusive and sustainable industrialization, if it stays on the BAU path. The country would also not be on track to meet the inequality reduction goals by 2030. Despite meeting the target for the contribution of the manufacturing industry to GDP, the BaU path creates only one third of the employment targeted in the manufacturing sector. Under the Agenda 2063, if Ethiopia continues with business as usual, it is on track to meet Incomes, jobs and decent work and Sustainable and inclusive economic growth targets. The Agenda 2063 goal on poverty, inequality and hunger will not be met under the BaU scenario despite an increase in per capita income. Inequality increases as the rural-urban divide widens.

Given that the BAU growth strategy will miss most of the goals of these three commitments, the paper has used simulations to asses other strategies. First, the model tests which would be better, agriculture, industry or service driven growth, for the goals of the three commitments. The results reveal that public investmentled productivity increase in agriculture contributes more to the number of jobs created and poverty headcount reduction compared to industry and services. The next question thus becomes "What is the best financing option for this agriculture led growth"? Looking at financing options, and comparing three options, revenue neutral; budget neutral and external financing, we test which option leads to the best results for financing investments in agriculture. Irrespective of financing option, an increase in budget allocation to agriculture brings about positive socioeconomic outcomes compared to the BaU. External financing of agricultural investments allows for the highest impact in terms of economic growth and socioeconomic outcomes to meet the targets of the three commitments.

Increasing productivity is the most effective compared to other forms of public investment followed by investments in physical capital in food processing and domestic trade of food and cash transfers to poor households. Public investment-led productivity increase in crops is the most effective in meeting the CAADP goals while livestock is the most effective for the SDGs. For the Agenda 2063 while fishery yields higher scores, crops, livestock and forestry are found to be equally effective. The CGE model is used to identify priority agricultural commodities based on their contributions to agricultural growth, and to income growth. The analysis reveals that nine commodities with the highest contribution are: maize, sorghum, teff, wheat, pulses, coffee, cattle, milk and sheep meat. 
In order to help guide the design of a financing strategy for agricultural development, alternative financing mechanisms and certain agricultural outputs in the value chain investment, are investigated. The analysis also discussed the milestones necessary to achieve the results found in the simulations. It is advised that these milestones, which are actionable results, be monitored to track progress towards achieving the Malabo, SDGs and Agenda 2063 goals and targets. What is important to note is that, scaling up the supply side investments cannot be sustained without increasing the demand side, including the mid-stream investments, i.e. agroindustry and internal trading of agriculture commodities. Agroindustry productivity increase has a limit that needs to be compensated by internal trading of agriculture commodities.

Therefore, a combination of transfers, cash and in kind, and investments in and for agriculture will be required. Specifically increasing productivity is more effective in attaining agricultural growth and higher income followed by investments in physical capital in food processing and domestic trade of food and cash transfers to poor households. Higher productivity in agriculture, agroindustry and in food domestic trade leads to higher effectiveness under the CAADP agenda followed by the Agenda 2063 and SDGs.

The growth in agricultural investment will have to come both from public and private investment. This would require the share of agriculture in public investment to double and reach a level much higher that CAADP target. To increase agricultural productivity sufficiently, intensity of input use needs to grow substantially, followed by total factor productivity and then agricultural production. In order to promote the required agricultural production growth, livestock and crop will need to grow by two digits growth rate. Some of the goals that cut across the three commitments are poverty reduction and eradication of hunger. In order to reduce extreme poverty and end hunger, the deceleration in the increase in local food prices will need to be complemented by higher consumer expenditure in rural areas. Furthermore, consumption of locally produced food will be critical in attaining poverty reduction goals. Stronger growth outside of the agricultural sector, in particular in rural areas, as well as social protection programs will help further reduce poverty and hunger. This will also contribute to reducing inequality between rural and urban populations. If Ethiopia were to successfully implement these recommendations, the results show considerable improvement in attaining the goals under Malabo, SDGs and Agenda 2063. 


\section{References}

African Union/New Partnership for Africa's Development (AU/NEPAD). 2003. Comprehensive Africa Agriculture Development Porgramme. Available online: http://www.nepad.org/caadp/publication/au-2003-maputo-declaration-agriculture-and-foodsecurity. Accessed January 2019

African Union/New Partnership for Africa's Development (AU/NEPAD). 2014. Malabo Declaration on Accelerated Agricultural Growth and Transformation for Shared Prosperity and Improved Livelihoods. Available online: http://www.nepad.org/caadp/publication/malabo-declarationaccelerated-agricultural-growth. Accessed January 2019

Fofana, I., Diallo,M.Y., Sarr,O., and Diouf, A., 2015. “2011 Social Accounting Matrix for Senegal.” IFPRI Discussion Paper 1417. Washington, DC.: International Food Policy Research Institute (IFPRI). http://ebrary.ifpri.org/cdm/ref/collection/p15738coll2/id/128960.

Fofana, I., Omolo, M.W.O., Goundan,A., Domgho ,L.V.M., Collins ,J., Marti, E., 2019. NAIP toolkit for Malabo domestication: Economic modeling of agricultural growth and investment strategy, case study of Kenya. IFPRI Discussion Paper 01813. Washington DC.

Lee, T. C., and C. G. Judge. 1996. "Entropy and Cross Entropy Procedure for Estimating Transition Probabilities from Aggregate Data.” In Bayesian Analyisis in Statistics and Econometrics, edited by D.A. Berry, K.A. Chaloner, and J. K. Geweke. New York: Wiley.

NEPAD, New Partnership for African Development. n.d. "The CAADP Results Framework (2015-2025).” http://www.nepad.org/resource/caadp-results-framework-2015-2025

Regional strategic Analysis and Knowledge Support System. 2017. Tracking data indicators for CAADP across countries and regions. Available online: http://www.resakss.org/index.php?pdf=45387. Accessed on 19/01/2019.

United Nations (UN) 2015. Transforming Our World: The 2030 Agenda for Sustainable Development. Available online: https://sustainabledevelopment.un.org/content/documents/21252030\%20Agenda\%20for\%20Sust ainable\%20Development\%20web.pdf. Access on 21/01/2019

World Bank. 2018. World Bank Open Data Bank. Available online: https://data.worldbank.org/. Accessed on 19/01/2019

World Bank. 2017. World Development Indicators. Available online: https://databank.worldbank.org/source/world-development-indicators. Accessed on January 2019. 
World Bank 2019. Ethiopia Economic Update 7. Special Topic: Poverty \& Household Welfare in Ethiopia, 2011-16.

Central Statistical Agency 2018. The 2015/16 Ethiopian Household Consumption Expenditure (HCE) Survey. Results for country level. Statistical Report.

Federal Democratic Republic of Ethiopia 2016. Growth and Transformation Plan II (GTPII) 2015/16 2019/20. Volume I: Main Text. National Planning Commission.

Ahmed, H.A., T. Tebekew and J. Thurlow. 2017. 2010/11 Social Accounting Matrix for Ethiopia: A Nexus Project SAM. International Food Policy Research Institute, Washington DC.

CSA (Central Statistical Agency), 2014b. Household consumption and expenditure survey 2010/11: analytical report. The Federal Democratic Republic of Ethiopia.

CSA (Central Statistical Agency), 2014. Agricultural Sample Survey 2009/10 to 2014/15. The federal Democratic Republic of Ethiopia. 


\section{Appendix}

Table 1: Effectiveness Score by Individual Agricultural Commodities

\begin{tabular}{|c|c|c|}
\hline Agricultural Commodities & Agricultural Growth & Income Growth \\
\hline Maize & $0.31 \%$ & $0.10 \%$ \\
\hline Sorghum & $0.42 \%$ & $0.10 \%$ \\
\hline Rice & $0.01 \%$ & $0.01 \%$ \\
\hline Teff & $0.33 \%$ & $0.14 \%$ \\
\hline Barley & $0.17 \%$ & $0.03 \%$ \\
\hline Wheat & $0.28 \%$ & $0.08 \%$ \\
\hline Pulses & $0.24 \%$ & $0.10 \%$ \\
\hline Ground nut & $0.01 \%$ & $0.00 \%$ \\
\hline Oil seeds & $0.08 \%$ & $0.00 \%$ \\
\hline Roots & $0.11 \%$ & $0.06 \%$ \\
\hline Vegetables & $0.27 \%$ & $0.14 \%$ \\
\hline Sugarcane & $0.05 \%$ & $0.00 \%$ \\
\hline Tobacco & $0.00 \%$ & $0.00 \%$ \\
\hline Cotton & $0.02 \%$ & $0.00 \%$ \\
\hline Fruit & $0.03 \%$ & $0.01 \%$ \\
\hline Enset & $0.24 \%$ & $0.13 \%$ \\
\hline Coffee & $0.33 \%$ & $0.08 \%$ \\
\hline Tea & $0.02 \%$ & $0.01 \%$ \\
\hline Chat & $0.09 \%$ & $0.05 \%$ \\
\hline Flower & $0.05 \%$ & $0.00 \%$ \\
\hline Oth crops & $0.05 \%$ & $0.02 \%$ \\
\hline Cattle & $0.38 \%$ & $0.37 \%$ \\
\hline Milk & $0.47 \%$ & $0.23 \%$ \\
\hline Poultry & $0.17 \%$ & $0.07 \%$ \\
\hline Sheep & $0.23 \%$ & $0.10 \%$ \\
\hline Goat & $0.19 \%$ & $0.08 \%$ \\
\hline Camel & $0.10 \%$ & $0.05 \%$ \\
\hline Oth livestock & $0.11 \%$ & $0.03 \%$ \\
\hline Forestry & $0.01 \%$ & $0.00 \%$ \\
\hline Fishery & $0.00 \%$ & $0.01 \%$ \\
\hline
\end{tabular}




\section{AGRODEP Working Paper Series}

0029. Natural Resource Curse in Africa: Dutch Disease and Institutional Explanations. Richard Mulwa and Jane Mariara. 2016.

0030. Have Migrant Remittances Influenced Self-Employment and Welfare among Recipient Households in Nigeria? Kabir Kayode Salman. 2016.

0031. Does Distance Still Matter for Agricultural Trade? Christian Ebeke and Mireille Ntsama Etoundi. 2016.

0032. Analyzing Trade Integration in North African Markets: A Border Effect Approach. Houssem Eddine Chebbi, Abdessalem Abbassi and Lota D. Tamini. 2016.

0033. Trade Performance and Potential of North African Countries: An Application of a Stochastic Frontier Gravity Model. Lota D. Tamini, Houssem Eddine Chebbi and Abdessalem Abbassi. 2016.

0034. Determinants of Cross-Border Informal Trade: The Case of Benin. Sami Bensassi, Joachim Jarreau, and Cristina Mitaritonna. 2016.

0035. The Welfare Effects of ICTs in Agricultural Markets: A Case of Selected Countries in East Africa. Mercyline Kamande and Nancy Nafula. 2016.

0036. Does an Inorganic Fertilizer Subsidy Promote the Use of Organic Fertilizers in Nigeria? Reuben Adeolu Alabi, Oshobugie Ojor Adams, and Godwin Abu. 2016.

0037. Why Can’t MENA Countries Trade More? The Curse of Bad Institutions. Reuben Fida Karam and Chahir Zaki. 2016.

0038. Female Labor Outcomes and Large-scale Land Investments in Tanzania. Evans S. Osabuohien, Raoul Herrmann, Uchenna R. Efobi, and Ciliaka M. W. Gitau. 2016.

0039. Assessing the Impact of Rice Sector Policy Reforms on the Income Mobility of Rural Households in Nigeria. Henry Okodua. 2017.

0040. Credit Constraints and Agricultural Productivity in Developing Countries: The Case of East Africa. Bethuel Kinyanjui Kinuthia. 2018.

0041. African Commitments for Agricultural Development Goals and Milestones for Cote d'Ivoire. Souleymane Sadio Diallo, Ismael Fofana, and Mariam Diallo. 2020.

0042. African Commitments for Agricultural Development Goals and Milestones for Niger. Souleymane Sadio Diallo, Ismael Fofana, and Mariam Diallo. 2020.

0043. African Commitments for Agricultural Development Goals and Milestones for Ethiopia. Lulit Mitik, Ismael Fofana, and Mariam Diallo. 2020. 